\title{
Identification and validation of cell surface antigens for antibody targeting in oncology
}

\author{
Paul Carter, Leia Smith and Maureen Ryan \\ Department of Antibody Technologies, Seattle Genetics, Inc., 21823 30th Drive SE, Bothell, Washington 98021, USA \\ (Requests for offprints should be addressed to P Carter; Email: pcarter@seagen.com)
}

\begin{abstract}
Recent clinical successes with antibodies have reinvigorated interest in the identification and validation of new antigens for antibody therapy, including cell surface proteins for targeting in oncology, the focus of this review. Target identification commonly involves the search for differences between tumor and non-tumor cell lines and/or tissue at the DNA, mRNA, protein or antibody reactivity levels. The next stage, target validation, utilizes antibodies to profile the expression of antigen in normal and tumor tissue and to verify that the antigen is selectively expressed on the surface of tumor cells. Supportive evidence for protein expression is often sought by mRNA profiling and, sometimes, analysis for genomic defects. Unfortunately, concordance between mRNA and protein levels has been found in only about $\sim 20 \%$ of cases and therefore must be evaluated for individual targets of interest. Antigens judged suitable for antibody targeting are then advanced to the next stage, namely, in vitro and then in vivo screening of antibodies for anti-tumor activities. Subsequent optimization of an antibody clinical lead for therapy is a desirable, if not obligatory, step to developing an antibody as an anti-cancer therapeutic. No single approach or even combination of methods has emerged as the preferred way to identify surface antigens suitable for targeting in oncology. Major options at each step in the process are reviewed here, including their strengths and limitations.
\end{abstract}

Endocrine-Related Cancer (2004) 11 659-687

\section{Introduction}

Antibodies are the most rapidly expanding class of human therapeutics, including their use in cancer therapy (Carter 2001, Glennie \& van de Winkel 2003). Indeed, eight antibodies are now approved for oncological indications in the USA and at least twenty-four more are being pursued actively in phase I/II clinical trials or beyond (Table 1). These clinical successes have reinvigorated interest in the identification of new targets for antibody therapy.

Here we review major alternative strategies for the identification of tumor-associated cell surface antigens and the validation of their suitability for antibody targeting in oncology, including antibody generation and screening for in vitro and in vivo anti-tumor activities (Fig. 1). Several important classes of antigens potentially amenable to antibody targeting in oncology are not covered here for space considerations: soluble factors, extracellular matrix proteins, and surface proteins on tumor neovasculature.

The first of four major steps is the acquisition of biological material for target identification such as tumor and closely related non-tumor cells. Tumor biopsies and resections provide an alternative or additional material source and ideally include a normal tissue counterpart for comparison. The second step, target identification, attempts to identify differences between the tumor and non-tumor samples at one of four levels: DNA, mRNA, protein or antibody reactivity. The third major activity, target validation, requires the generation of antibodies as reagents to profile the expression of the antigen in normal and tumor tissue. Corroborating evidence is often sought by mRNA profiling and, where appropriate, analysis for genomic defects. The use of mRNA profiling data necessitates evaluation of the concordance between mRNA and protein levels for the target of interest, as such concordance is not common: $\sim 20 \%$ of genes and 


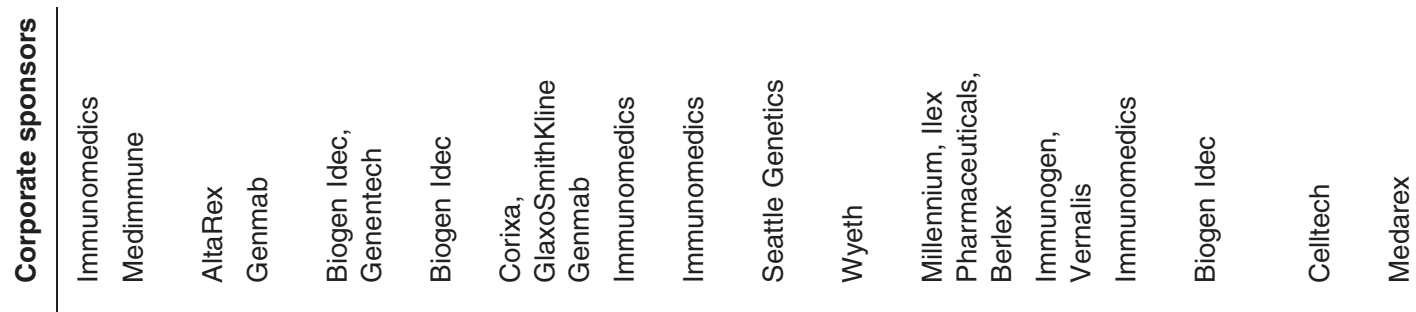

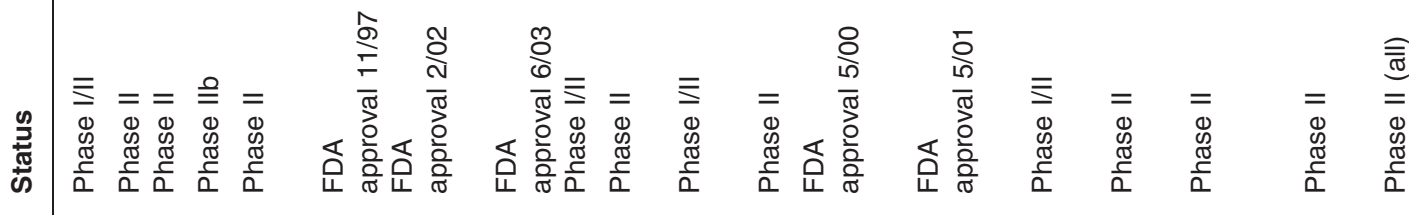

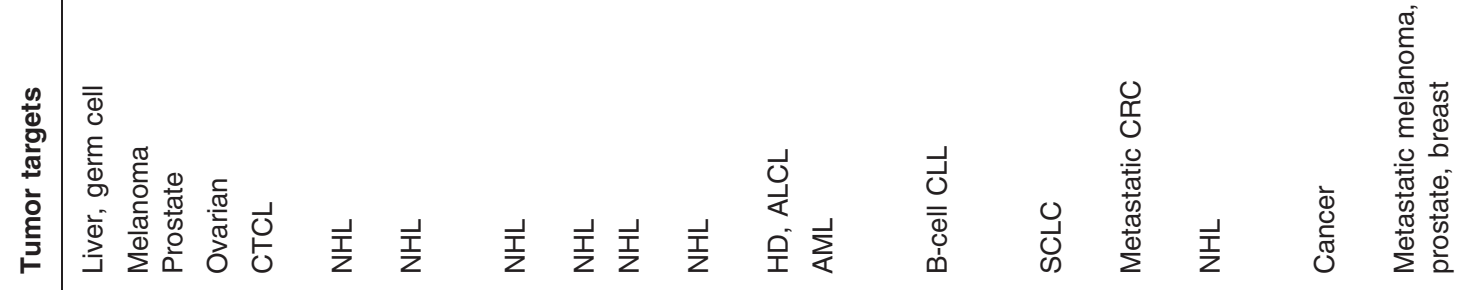

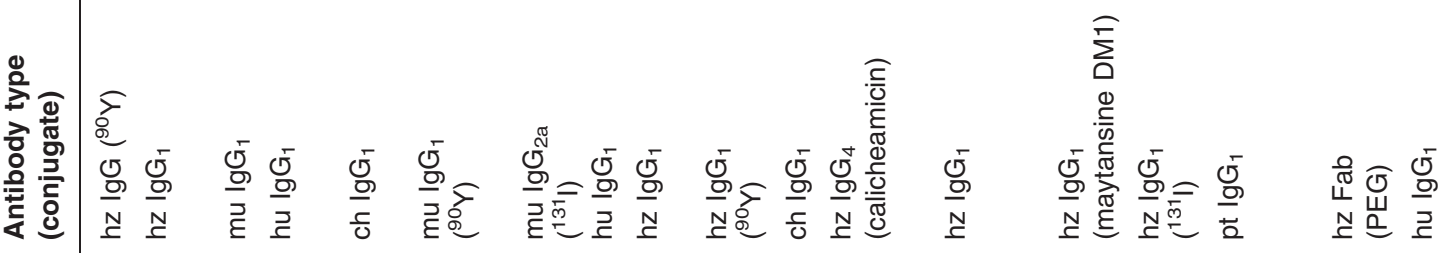

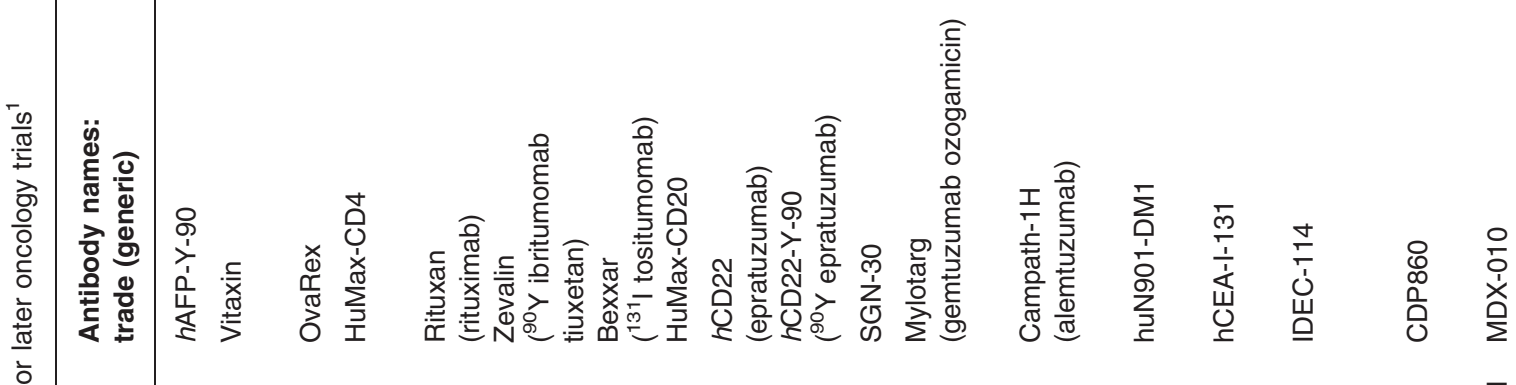

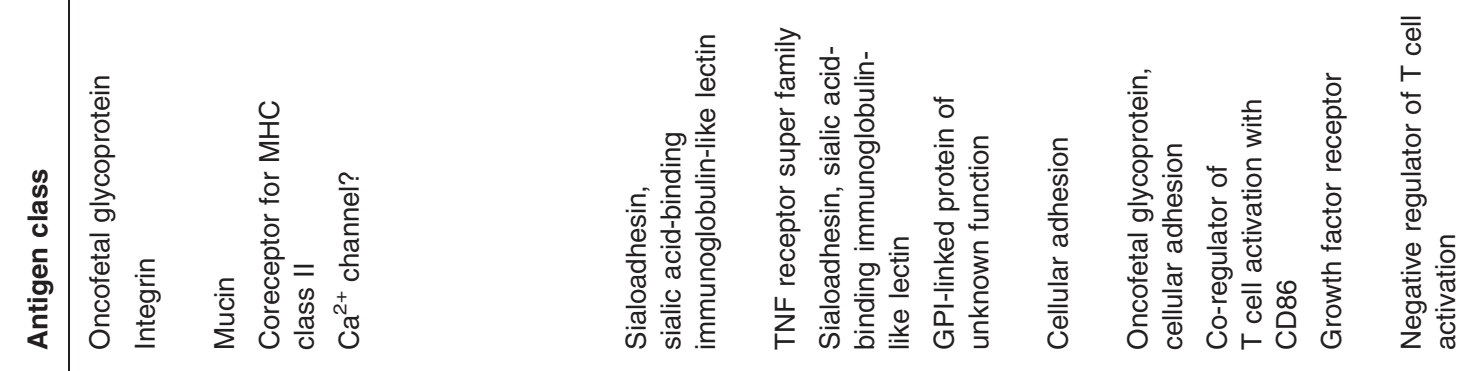




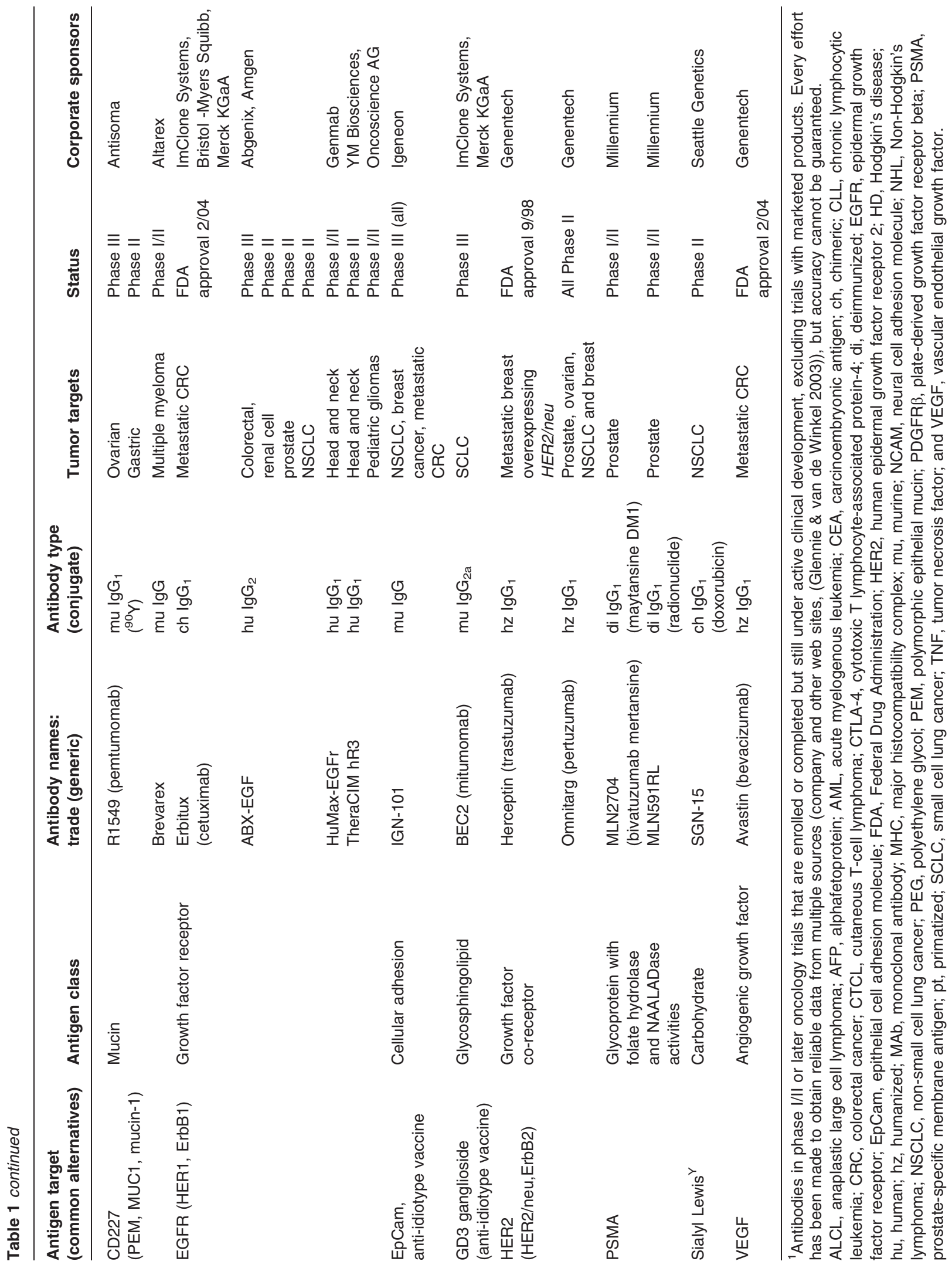




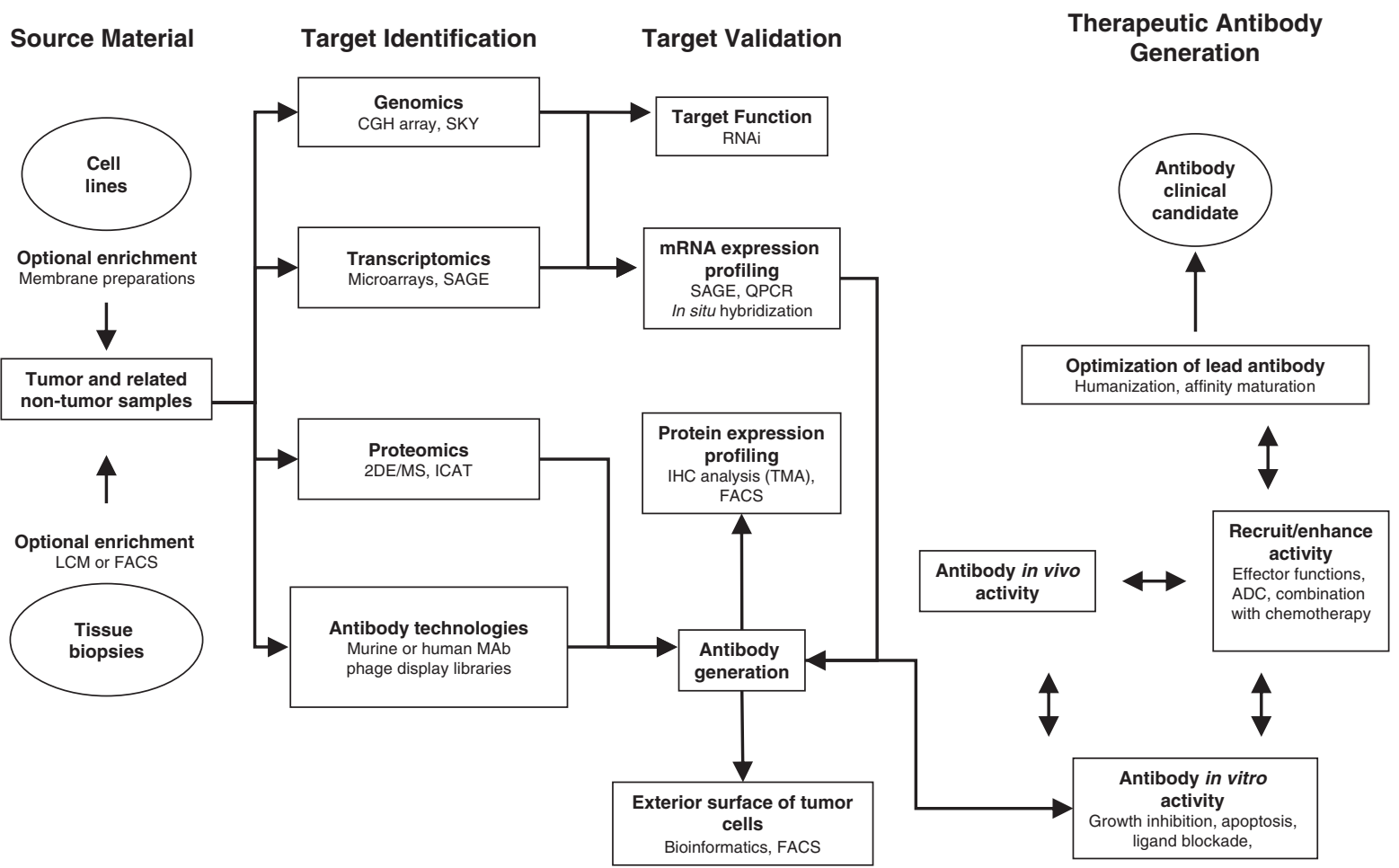

Figure 1 Overview of major strategies for the identification of tumor-associated cell surface antigens and validation of their suitability for antibody targeting in oncology. 2DE/MS, 2-dimensional electrophoresis/mass spectrometry; ADC, antibody drug conjugate; CGH, comparative genomic hybridization; FACS, fluorescence-activated cell sorting; ICAT, isotope-coded affinity tag; IHC, immunohistochemistry; LCM, laser capture microdissection; MAb, monoclonal antibody; QPCR, quantitative real time PCR; RNAi, RNA interference; SAGE, serial analysis of gene expression; SKY, spectral karyotyping; TMA, tissue microarray.

proteins in the largest study to date (Chen et al. 2002a). Beyond any bioinformatic prediction, it is imperative to establish experimentally that a protein is localized to the plasma membrane and has extracellular determinants amenable to antibody targeting. The fourth major step is the in vitro and subsequent in vivo screening of panels of antibodies for the desired anti-tumor activities. Intellectual property considerations, critical to the commercial development of antibody drugs, are outside the scope of this article.

\section{What makes a cell surface antigen suitable for antibody targeting in oncology?}

Defining desirable antigen characteristics is a critical starting point for the identification of new cell surface targets for antibodies. A favorable antigen expression profile is a multi-faceted aspect of antigen characterization that is anticipated to be a necessary but not sufficient condition for successful tumor targeting with an antibody. An ideal expression profile is abundant and homogeneous antigen expression on the external surface of all tumor cells for multiple tumor types with the majority of patients for each tumor type, and absent from normal tissue. It is not necessary to fully satisfy all of these criteria as evidenced by clinical approval of antibodies targeting HER2 (Herceptin), CD20 (Rituxan, Zevalin and Bexxar), CD33 (Mylotarg), CD52 (Campath) and epidermal growth factor receptor (EGFR) (Erbitux) (Table 1). The extent to which an antigen can deviate from an ideal expression profile and still be amenable to antibody targeting is, as yet, unknown. The complexity of this question encourages the empirical approach of establishing criteria from existing antibody drugs and refining them based upon future experience in preclinical and clinical cancer therapy. Below is a discussion of important aspects of antigen expression on tumors and normal tissue anticipated to be critical to successful antibody targeting of tumors.

A key facet of antigen expression on tumor cells that will potentially impact antibody targeting is any change in expression that occurs during the course of disease. Minimally the target antigen should be associated with advanced cancer to reflect the patient populations most commonly available to experimental drugs. Preferably, the antigen will be present in tumors at all stages of disease, 
including metastatic foci, to provide a potentially broader opportunity for treating patients. Most desirably the antigen will be causally involved in disease pathogenesis, as exemplified by HER2 (Di Fiore et al. 1987, Hudziak et al. 1987), to reduce the likelihood that tumors will escape from antibody therapy by antigen down-modulation. Antigen expression restricted to early stage cancer appears impractical for antibody drug development for the following reasons. First, there is a risk that diagnosis of cancer will not occur until after antigen expression has been lost. Secondly, patients with early stage disease will often have established treatment options that preclude the use of an unproven experimental drug.

Homogeneous expression of antigen on tumor cells is desirable for antibody targeting but is not necessarily a critical factor for success. However, heterogeneous expression of antigen on tumor tissue may necessitate endowing the antibody with a means to kill bystander tumor cells, e.g. by conjugation to radionuclides or drugcontaining liposomes, or fusion to cytokines or an enzyme for prodrug activation (Carter 2001, Milenic 2002, Presta 2002, Glennie \& van de Winkel 2003, Ross et al. 2003a).

A priori, there will be a lower limit of antigen expression on tumors that will support effective in vivo targeting and anti-tumor activity of an antibody. This lower limit of antigen expression for supporting antibody efficacy is unknown and arguably best defined empirically, given the multitude of parameters related to antibody, antigen and tumor that may potentially impact it. Clinical examples offer at least crude upper estimates for the minimal antigen levels required to support successful antibody targeting. Tumor cells in non-solid tumors such as leukemias and lymphomas are commonly more accessible to antibodies than those in solid tumors and this may potentially impact the minimal antigen level required for supporting successful antibody targeting.

In the case of non-solid tumors, as few as 100000 copies of antigen per cell can be sufficient for effective anti-tumor activity of a naked antibody as judged by CD20 expression levels in non-Hodgkin's lymphoma (Glennie \& van de Winkel 2003) and the efficacy of Rituxan (Table 1). For the antibody drug conjugate, Mylotarg, anti-tumor activity against the non-solid tumor, acute myelogenous leukemia, has been observed with as few as $\sim 5000-10000$ copies (Tanimoto et al. 1989) of the CD33 antigen per cell (Table 1).

As for successful antibody targeting of solid tumors, Herceptin is an example where patient responsiveness apparently requires very high levels of expression of the cognate antigen, HER2. Indeed, Herceptin used as a single agent in first-line treatment of metastatic breast cancer gave a response rate of $35 \%$ and $0 \%$ in 111 evaluable patients with immunohistochemistry (IHC) staining of $3+$ and $2+$ respectively (Vogel et al. 2002). Bench-marking these IHC data with cell lines suggests that $3+$ and $2+$ staining corresponds to about $2.3 \times 10^{6}$ and $5 \times 10^{5}$ copies of HER2 per cell, respectively (Ross et al. 2003b). Thus clinical activity of Herceptin correlates broadly, but not invariably, with HER2 expression level. Preclinically, the antibody-dependent cellular cytotoxicity (ADCC) activity of Herceptin generally correlates with antigen expression level as does anti-proliferative activity of Herceptin's parent monoclonal antibody (MAb), 4D5 (Lewis et al. 1993). Successful antibody targeting of tumors expressing lower levels of HER2 may be possible as judged by Omnitarg, a humanized version of MAb 2C4. Omnitarg (Table 1) has in vivo anti-tumor activity against MCF7 xenografts expressing low levels of HER2, where Herceptin has no activity (Agus et al. 2002). Partial responses were observed in 3 of 21 patients treated with Omnitarg in a phase I clinical trial (DeGrendele 2003). Omnitarg is currently in multiple phase II clinical trials (Table 1).

Beyond tumors, expression of antigen on normal tissue is a key factor in assessing the suitability of an antigen for antibody targeting in oncology. Limited or preferably no antigen expression on vital normal tissue is desirable to minimize the risk of antigen-dependent toxicities resulting from antibody therapy. This is a particularly important issue for antibodies that are 'armed' with drugs, toxins or radionuclides to increase the anti-tumor potency. Expression on non-vital tissue appears less problematic, provided that the antigen sink is sufficiently small to avoid major perturbation of the pharmacokinetics or pharmacodynamics of a therapeutic antibody. Antibody targeting may also potentially be possible for an antigen whose expression is restricted to a non-vital organ or cell population, even if the antigen is not differentially expressed between normal and tumor tissue. For example, CD20, CD33 and CD52 are markers for B cells, myeloid progenitors plus monocytes, and leucocytes, respectively - cell lineages that can be eliminated on a temporary basis.

Many known tumor antigens are expressed at low levels on some normal tissues and substantially higher levels on some tumor cells (Schlom 1991). Can such differential antigen expression be exploited to enhance the selectivity of antibody targeting to tumors in vivo? Mathematical modeling suggests that this may be possible by judicious tuning of the antigen-binding of an antibody such that it is high enough to enable localization to tumor cells expressing high levels of antigen but too low for significant accrual within normal tissue that expresses low level of antigen (Crombet et al. 2004). Clinical experience with anti-EGFR antibodies (Table 1) hR3 (Crombet et al. 2004), Erbitux (Mendelsohn 2000) and ABX-EGF (Foon 
et al. 2004) is broadly consistent with this hypothesis, but does not provide a direct test. The antigen binding affinities $\left(K_{\mathrm{D}}\right)$ of $\mathrm{hR} 3$, Erbitux and ABX-EGF are $10^{-9} \mathrm{M}, 2 \times 10^{-10} \mathrm{M}$ and $5 \times 10^{-11} \mathrm{M}$, respectively. Each of these three anti-EGFR antibodies has shown anti-tumor activity in one or more tumor types where the antigen level is very high $\left(\sim 10^{6}\right.$ copies per tumor cell). In contrast, Erbitux and ABX-EGF commonly give rise to rashes on skin $\left(\sim 10^{4}\right.$ copies of EGFR per cell) that has not been observed with hR3. Antigen binding affinity is one of many possible explanations for the differences in toxicity profile between $\mathrm{hR} 3$ and other anti-EGFR antibodies (Crombet et al. 2004).

Shed antigen can potentially interfere with antibody therapy of tumors by several inter-related mechanisms including acceleration of antibody clearance, impairment of antibody localization to tumor and by untoward effects of any immune complexes formed. Ideally the target antigen is not shed (e.g. CD20, Einfeld et al. 1988) or at least shed at only low $(<500 \mathrm{ng} / \mathrm{ml})$ and antibodytitratable levels in the majority of patients (e.g. HER2, Baselga et al. 1996, Cobleigh et al. 1999).

\section{Source material}

Selection and acquisition of biological source material such as cell lines and/or clinical samples is a critical step prior to target identification. Cell lines are the most commonly used starting material as they are readily available and propagated to provide sufficient material for any common target identification strategy. Moreover, the handling of cell lines can be closely controlled and optimized to preserve sample integrity.

A major caveat of using cell lines for target identification is that they will differ from primary tumor samples in ways and to an extent that is unknown. Indeed, both overlap and distinct differences have been observed between the gene expression profiles of primary tumor samples and tumor cell lines (Zhang et al. 1997). Thus targets will be missed if they are upregulated in primary human tumor tissue but not in tumor cell lines - false negatives. Conversely, targets may be found that are upregulated in tumor cell lines but not in primary tumor tissue - false positives.

Several strategies can be used to reduce the impact of false positive or negative findings from target identification using cell lines. First, the use of multiple cell lines in parallel may highlight findings specific to individual cell lines. Secondly, it may be possible to reduce the differences between cell lines and primary human tissue by in vivo passaging of cell lines. Alternatively, mRNA expression profiling of cell lines alongside clinical samples may allow identification of a cell line whose mRNA expression profile most closely matches clinical specimens (K Wilson, unpublished observations). Target validation by protein and mRNA expression profiling of patient samples provides a means to eliminate false positive findings derived from the use of tumor cell lines for target discovery.

Clinical samples are the most relevant source of biological material for the identification of new tumor targets. Unfortunately, the use of patient tissue for target identification has been significantly stymied by the time, effort and cost of addressing legal and ethical issues related to the procurement and use of tissues. Ideally, one has sufficient control over tissue acquisition, handling and storage to preserve sample integrity. Minimally, one needs rigorous quality control and stringent sample selection so that poor quality materials are excluded to avoid compromising further analysis.

Another limitation of using human tissue for target identification is that biopsy material may contain a mixture of tumor and non-tumor tissue that confounds detection of molecular differences between tumor and non-tumor. The impact of sample heterogeneity can be minimized by setting stringent criteria for tissue usage, e.g. tumor represents $>70 \%$ of the sample (Beer et al. 2002). Alternatively, clinical samples can be enriched for tumor cells by laser capture micro-dissection (LCM) (Emmert-Buck et al. 1996) or by fluorescence-activated cell sorting (FACS) (Herzenberg et al. 2002) (Table 2). Enrichment for tumor cells may present challenges of obtaining human material in sufficient quantity and quality to support the target identification method of interest. Primary human tumor tissue can potentially be propagated in immune-deficient mice or limited culture in soft agar to provide more material, but at the risk of changes in antigen expression impacting subsequent analysis.

Further complexity in comparing tumor and nontumor tissue arises from 'field cancerization', a concept first introduced on observation of histologically abnormal cells surrounding oral squamous cell carcinoma and proposed to explain the development of multiple primary tumors and local cancer recurrences (Slaughter et al. 1953). The presence of field cancerization with genetically altered preneoplastic cells has subsequently been reported in several different epithelial cancer types by independent investigators as reviewed by Braakhuis et al. (2003). A major clinical consequence of cancerization fields is that they may lead to local cancer recurrence if not surgically removed with the primary tumor (Tabor et al. 2004). Unfortunately, cancerization fields are not always evident at the macroscopic level as evidenced by genomic aberrations (loss-of-heterozygosity) in apparently 'normal' mucosa adjacent to head and neck squamous cell 


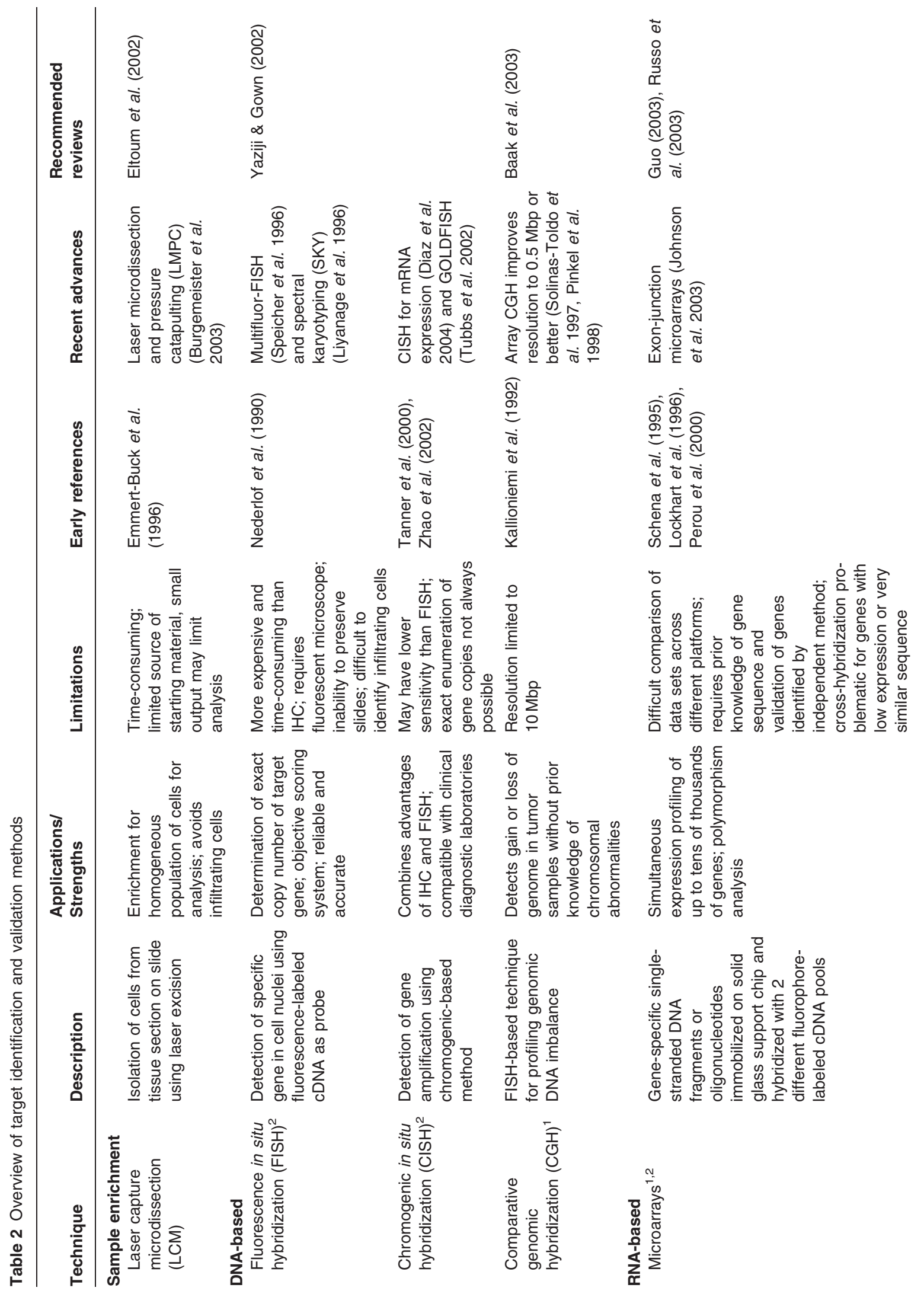




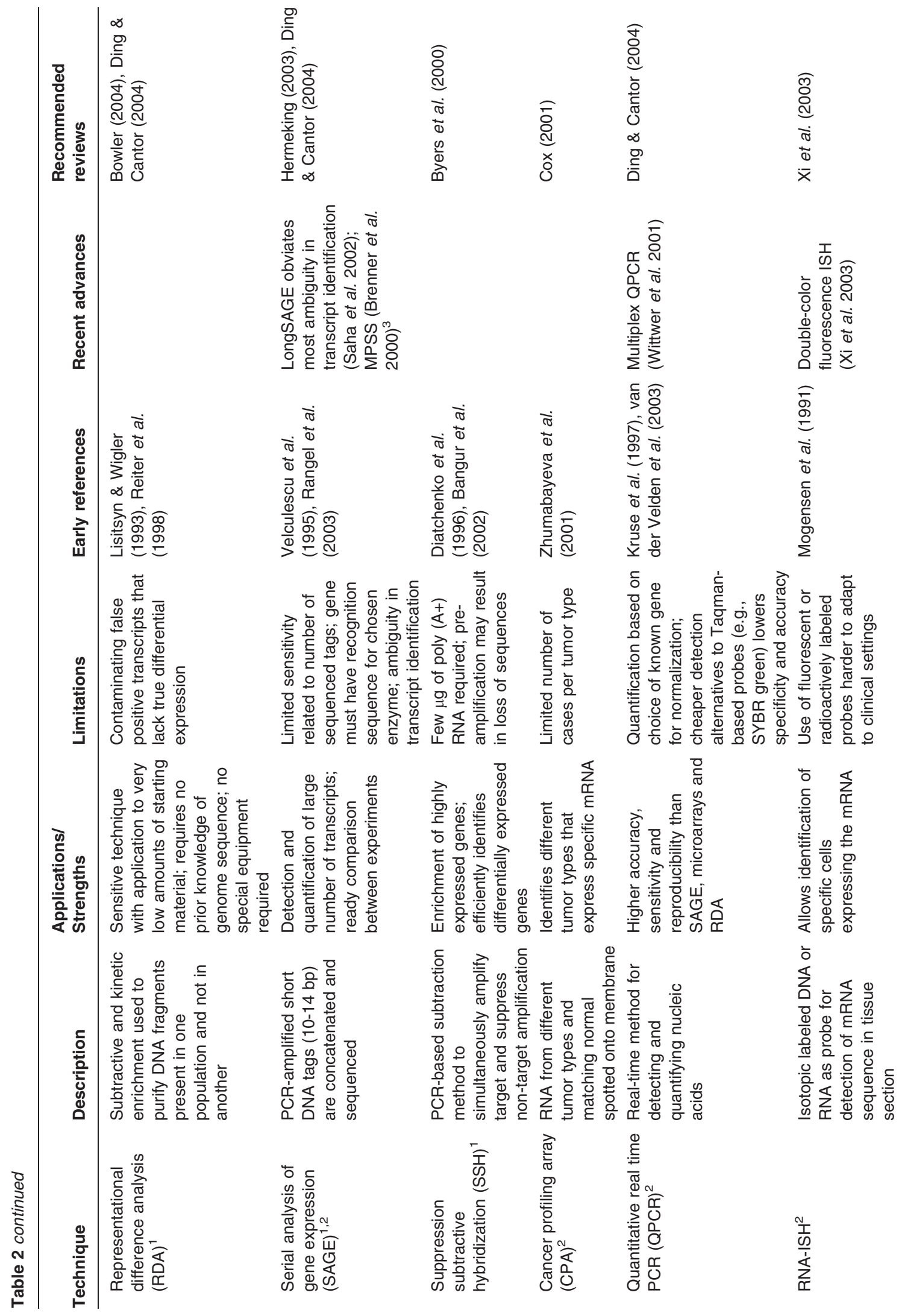




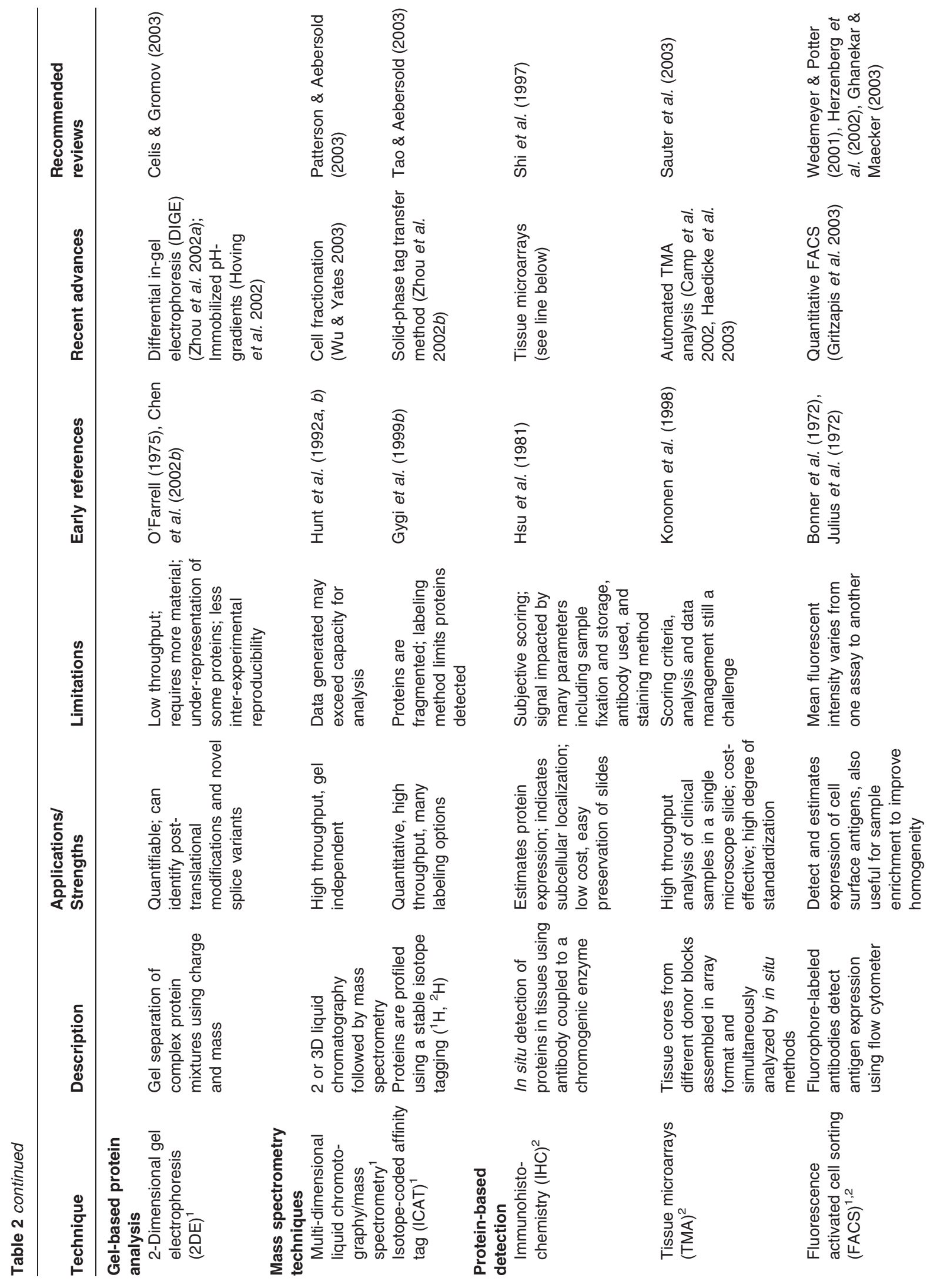




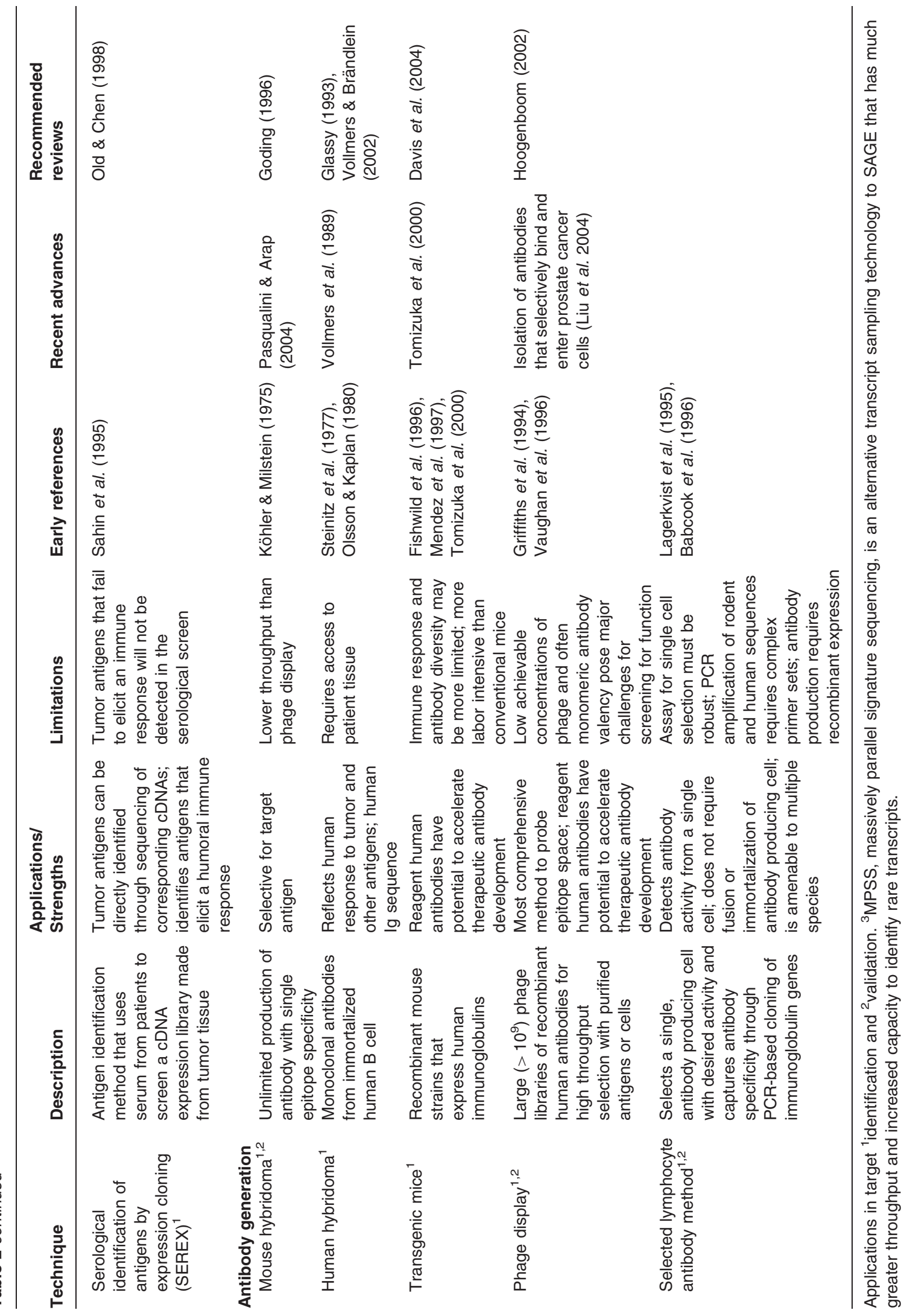


carcinoma (Tabor et al. 2001). Such field cancerization has the potential to confound comparison of tumor and non-tumor tissue in target identification and validation. Therefore, acquisition of distant but relevant normal tissue from the same individual is recommended when comparing tumor tissues with normal counterparts.

\section{Identification of tumor-associated cell surface targets}

Target identification and validation utilize a complex web of different methods to search for differences between tumor and non-tumor cell lines and/or tissue at the DNA, mRNA, protein or antibody reactivity levels (Fig. 1). Major techniques used for the discovery of tumor antigens are defined in Table 2 including their key applications, strengths, limitations, recent advances, and representative references.

Sequencing of the human genome (Lander et al. 2001, Venter et al. 2001) has greatly facilitated target discovery, e.g. by expanding the database of known and predicted proteins and providing critical mapping data for the identification of novel cancer genes. Many technologies for target discovery and validation are new and are still evolving rapidly. In contrast, the development of antibody, and other, drugs has commonly taken one or two decades from target identification through regulatory approval. Therefore, it remains to be seen which emergent technologies will have the greatest impact upon drug development.

\section{Genomics}

Alterations in the genome associated with cancer include localized changes such as substitutions, deletions and insertions within genes, medium scale aberrations as exemplified by gene amplification and deletions and larger scale defects including chromosomal translocations (Strausberg et al. 2003). In principle, all classes of cancer-associated genomic defects, with the exception of epigenetic events, can be identified by whole genome sequencing of tumor versus matched normal tissue. Currently, whole genome sequencing of tumor versus matched normal tissue is too laborious and expensive to be attractive for target discovery. Fortunately, several alternative techniques are available that allow particular types of genomic defects to be identified (Baak et al. 2003, Strausberg et al. 2003). Somatic mutations and allelic loss in tumor cells can be detected using heteroduplex analysis and loss of heterozygosity respectively. Comparative genomic hybridization ( $\mathrm{CGH}$ ) probes gene copy number and is well suited to the identification of gene amplifications and deletions, whereas spectral karyotyping (SKY) is particularly useful for the study of chromosomal translocations (Table 2).

The identification of genomic defects causally involved in cancer pathogenesis has already led to important new anti-cancer drugs as evidenced by the small molecule, Gleevec (imatinib mesylate), approved for the treatment of chronic myelogenous leukemia (Druker 2002). Gleevec inhibits the enzymatic activity of the hybrid kinase created by chromosomal translocation and fusion of the BCR and ABL genes. Genomic analysis can sometimes provide insights into the molecular basis of responsiveness to drugs as illustrated by Iressa (gefitinib), a small molecule inhibitor of the EGFR tyrosine kinase, approved for the treatment of non-small cell lung cancer (NSCLC). About $10 \%$ of NSCLC patients treated with Iressa exhibit a rapid and often dramatic anti-tumor response. DNA sequence analysis has revealed that the majority of Iressa responders have mutations in the ATPbinding pocket of the EGFR tyrosine kinase domain. In vitro, these EGFR mutations lead to enhanced tyrosine kinase activity in response to EGF and increased sensitivity to Iressa (Lynch et al. 2004, Paez et al. 2004).

The discovery of a genomic defect that ultimately led to an antibody therapeutic for cancer is illustrated by the HER2 gene and Herceptin (Table 1). The HER2 gene is amplified in about $25-30 \%$ of breast and ovarian cancer patients and is predictive of overall survival and time to relapse (Slamon et al. 1987, 1989). These seminal observations eventually led to the development of the humanized anti-HER2 antibody, Herceptin, now approved for the treatment of metastatic breast cancer (Carter et al. 2000).

\section{Transcriptomics}

Global profiling of mRNA levels - transcriptomic analysis - across large numbers of tumor samples has become commonplace using cDNA or oligonucleotide microarrays or serial analysis of gene expression (SAGE) (Table 2) (Ruan et al. 2004). Expression profiling has recapitulated prior histopathological classifications and in some cases has identified new tumor subtypes that correlate with disease progression and/or treatment outcome. Expression profiling has been undertaken for many cancers including acute leukemias (Golub et al. 1999), large B cell lymphoma (Alizadeh et al. 2000) and breast cancer (Perou et al. 2000, Sørlie et al. 2001, van't Veer et al. 2002). By comparing transcription profiles using three different methodologies (oligonucleotide microarray, SAGE, and principal component analysis (PCA)), gene expression profiling in pancreatic ductal adenocarcinomas identified a novel set of highly expressed genes as well as validated differential expression of previously reported genes (Iacobuzio-Donahue et al. 2003). The inclusion of 
PCA is another tool in the study of identified patterns from the long list of differentially expressed genes produced from transcript profiling techniques and data is stratified to highlight promising candidates for translation into clinical targets. Thus, transcriptomic analysis is a robust and broadly applicable tool for the identification of diagnostic and prognostic gene expression signatures for cancer, as well as for potential therapeutic targets.

The use of mRNA profiling to identify proteins amenable to antibody targeting assumes that mRNA levels correlate with protein levels. Unfortunately, limited concordance between mRNA and protein expression has generally (Chen et al. 2002a,b, Smith et al. 2002, Souchelnytskyi 2002), but not always (Kern et al. 2003), been observed. Indeed, in the largest study to date, only $17 \%$ of protein spots $(n=165)$ or $21 \%$ of genes $(n=98)$ had a statistically significant correlation between protein and mRNA expression (Chen et al. 2002a). The potential for discordance between mRNA and protein levels is a major drawback to the use of RNA-based methods for the identification of cell surface targets.

These limitations notwithstanding, mRNA-based methods have identified a few cell surface targets associated with cancer such as prostate stem cell antigen (PSCA) (Reiter et al. 1998), or further implicated known cell-surface proteins with cancer, including $\mathrm{E}$ selectin (Bhaskar et al. 2003) and EphB2 (Mao et al. 2004). PSCA was identified by representational difference analysis (RDA, Table 2) as being upregulated in an androgenindependent prostate cancer xenograft (Reiter et al. 1998). PSCA protein expression was subsequently observed in $94 \%(n=112)$ of primary prostate tumors and all $(n=9)$ bone metastases (Gu et al. 2000). More recently, an antiPSCA antibody drug (maytansinoid) conjugate was found to have robust anti-tumor activity in a tumor xenograft study (Ross et al. 2002).

\section{Splice variants}

A promising branch of transcriptomics is the analysis of mRNA splice variants associated with human disease, including cancer. Alternative splicing is a common mechanism that increases the number and variability of transcripts made from a single gene. A survey of $>10000$ human genes across 52 tissues and cell lines revealed that $74 \%$ of the multi-exon genes were alternatively spliced (Johnson et al. 2003). Tumor-associated splice variants have been identified for numerous genes including $\mathrm{E}$ cadherin (Becker et al. 1994), EGFRvIII (Sugawa et al. 1990), CD44 (Heider et al. 1993, Wielenga et al. 1993), and HER-4 (Junttila et al. 2000, Gilbertson et al. 2001, Gilmour et al. 2001). Splice variants are detected by many methods including cDNA cloning (Gunthert et al. 1991), RT-PCR (Sturla et al. 2003), expressed sequence tags
(Correa et al. 2000) and exon junction microarrays (Johnson et al. 2003).

Tumor-associated splice variants are highly attractive targets in that antibodies can be directed towards a protein domain uniquely expressed on the tumor cell surface but absent from normal tissues, as illustrated by EGFRvIII (Wikstrand et al. 1995) and E-cadherin (Becker et al. 2002). Antibodies to EGFRvIII have proved efficacious in tumor xenograft models (Luwor et al. 2001, Mishima et al. 2001, Johns et al. 2003). The EGFRvIII splice variant occurs with high frequency in gliomas and apparently in a significant subset of other tumor types (Moscatello et al. 1995, Wikstrand et al. 1995). In contrast, the exon 9 deletion variant of $E$ cadherin appears to be uncommon as judged by its detection in about $8 \%$ of diffuse gastric cancers (Becker $e t$ al. 1999). Thus, the prevalence of splice variants can vary widely and must be evaluated carefully in validating this class of antigens for antibody targeting.

Tumor-associated splice variants have also been detected for extracellular matrix proteins as exemplified by fibronectin (Zardi et al. 1987, Carnemolla et al. 1989). Such molecules can also provide potential targets for antibodies in oncology. For example, an antibody fragment targeting the ED-B domain of fibronectin, an extracellular matrix protein variant, has been genetically fused to tissue factor (Nilsson et al. 2001), interleukin (IL)-2 (Carnemolla et al. 2002) and IL-12 (Halin et al. 2002), allowing targeted delivery of these factors to tumors with encouraging anti-cancer efficacy.

\section{Proteomics}

Genomic and transcriptomic analysis are indirect methods for the discovery of cell surface targets that necessitate subsequent validation at the protein level. In contrast, proteomic methods can be tailored to search directly for targetable cell surface features that distinguish cancer cells from normal cells. A further advantage of proteomic over genomic and transcriptomic methods is that they can explore differences in post-translational modification, a potentially valuable source of targets. For example, the mucin product of the MUC1 gene is overexpressed and under-glycosylated in many human tumors (Barratt-Boyes 1996), exposing new epitopes for antibody targeting that are transparent to DNA- and RNA-based methodologies.

Mass spectrometry (MS) methods have emerged as the tools of choice for identifying disease alterations at the protein level (Hanash 2003). Profiling cancer cells and tissue to identify quantitative and qualitative differences in proteins was pioneered using 2-dimensional electrophoresis (2DE) and MS (Celis \& Gromov 2003). A strong advantage of a gel-based technique such as 2DEMS is that post-translation modifications, proteolytic 
cleavage and polypeptide variation can be detected within the context of an intact, endogenous protein. 2DE has identified many proteins that are differentially expressed and/or modified in cancers including bladder carcinoma (Celis et al. 1996, 1999, Ostergaard et al. 1997), melanoma (Bernard et al. 2003), lung adenocarcinoma (Oh et al. 2001, Chen et al. 2002b), breast carcinoma in situ (Wulfkuhle et al. 2002) and leukemia (Hanash et al. 1986, 1988, Melhem et al. 1997).

Early application of 2DE-MS for global protein analysis has highlighted the use of protein profiles as diagnostic and/or prognostic indicators of cancer. However, downstream studies on target molecules identified through 2DE-MS studies have led to a greater understanding of their biological role in cancerous pathways. For example, oncoprotein 18 (Op18) is a phosphorylated protein that was initially identified by 2DE as being over-expressed in leukemias (Hanash et al. 1988). Subsequent studies showed that Op18 regulates cell proliferation and microtubule assembly, and warrants exploration as a potential therapeutic target for leukemia and other cancers (Hanash et al. 2002).

Advances notwithstanding, the utility of 2DE-MS for profiling the cell surface proteome is limited by the relative insolubility of membrane-associated proteins under conditions suitable for 2-DE and the inability to detect proteins that are low in abundance (Flory et al. 2002). Consequently, alternative strategies have been pursued to enrich extracts for plasma membrane targets and improve sensitivity. For example, membrane fractionation in conjunction with one-dimensional (1DE)-MS identified new, as well as known, breast cancer targets (Adam et al. 2003). Fractionation to enrich for membrane-associated proteins is also commonly used in combination with multi-dimensional liquid chromatography (LC) and MS (Han et al. 2001, Wu et al. 2003, Wu \& Yates 2003). Multi-dimensional LC-MS provides the high sensitivity and throughput required for clinical sample analysis (Flory et al. 2002, Hanash 2003). Protein quantification and reduction in sample complexity can be achieved with gel-independent methods such as isotopecoded affinity tags (ICAT, Table 2) (Gygi et al. 1999a). ICAT combines affinity tags with either a 'heavy' or 'light' stable isotope label so that proteins from two different samples (e.g. tumor and non-tumor) can be compared and analyzed by MS in a quantitative fashion. ICAT methodology has been used in combination with multidimensional liquid chromatography to identify and quantify cell surface proteins in the microsomal fraction of differentiated HL-60 cells (Han et al. 2001) and to analyze the secreted and cell surface proteins from a prostate tumor line in response to androgen treatment (Martin et al. 2004).
Proteomics, like gene expression profiling, has defined new subclasses of disease and holds significant promise for the identification of new 'drugable' targets. However, given the inherent diversity of protein properties, proteomic methods seem unlikely to become as facile, high throughput or universal as DNA or mRNA profiling. Furthermore, even as the throughput of proteomics increases, improvements will be tempered by bioinformatic limitations and by the labor required to validate individual targets by western blot and IHC. Alternative strategies that implement either protein or antibody chips for global analysis of tumor proteins or patient serum are currently being developed and will likely further increase the impact of proteomics in medicine (Jenkins \& Pennington 2001, Mitchell 2002, Mintz et al. 2003).

\section{Antibody technologies}

Antibody methods (Table 2) provide the most direct and comprehensive route to the identification of antibodytargetable differences between tumor cells and non-tumor cells. A further advantage is that antibodies generated for target discovery are multi-purpose tools that can be applied to target validation, and potentially clinical lead generation (Fig. 1). Indeed, validation of target expression is integral to the antibody screening and selection process. In contrast, other discovery methods require antibodies for target expression profiling at the validation stage. Antibody-based discovery has the potential to illuminate the full epitope space of the tumor cell surface including protein products of splice variants, post-translational modifications of proteins, and glycolipids that are invisible, or at least only opaque, to other discovery methods.

These major attractions of antibody-based discovery are significantly offset by two substantial and compounding limitations. First, antibody-based discovery has much lower throughput than many genomic, transcriptomic and some proteomic methods. Secondly, much time and effort may be extended to establish that an antibody has a favorable binding profile on tumor and non-tumor cells only to discover that the target lacks novelty from either a scientific or intellectual property perspective. This reflects the fact that one typically screens large numbers of antibodies by expression profiling prior to the identification of the cognate antigen by MS (Nasdala et al. 2002) or, less commonly nowadays, by N-terminal sequencing of the protein or expression cloning of the corresponding gene (Ridgway et al. 1999). This antigen identification bottleneck for antibody-based discovery is overcome by SEREX - serial identification of antigens by expression cloning (Sahin et al. 1995). SEREX obviates the need for target identification at the protein level since it directly identifies tumor antigens by serological screening of 
cDNA expression libraries from human tumors (Table 2). The power of the SEREX technology resides in the ability to identify antigens eliciting a humoral immune response. A limitation of SEREX is that it does not directly yield a replenishable antibody supply. Specific methods of antibody generation, together with the strengths and challenges posed by each method, are highlighted in subsequent sections.

The five major technologies used for monoclonal antibody generation are murine hybridomas, human hybridomas from mice transgenic for human immunoglobulin (Ig) genes, human hybridomas derived from patients, antibody phage display libraries, and recombinant antibody production from single, antigen-selected lymphocytes (Lagerkvist et al. 1995, Babcook et al. 1996). Murine hybridoma technology is the most widely used method for MAb generation for research applications. Unfortunately, the clinical development of murine MAbs has commonly been confounded by a strong cross-species immune response. The immunogenicity of murine MAbs has often been reduced to inconsequential levels by chimerization or preferably humanization, as extensively reviewed elsewhere (Carter 2001, Brekke \& Sandlie 2003, Glennie \& van de Winkel 2003). Murine MAb humanization can be obviated by using human MAb from phage display libraries (Hoogenboom 2002), transgenic mice that express human antibodies (Davis et al. 2004), patients (Vollmers \& Brändlein 2002), or selected lymphocyte antibody methods (Babcook et al. 1996) (Table 2). Whilst human antibodies have the potential to streamline preclinical development, each method for human $\mathrm{MAb}$ generation poses unique challenges for research applications (see below).

\section{Monoclonal antibodies}

Hybridomas producing MAbs are generated from the stable fusion of immortalized myeloma cells with B cells from immunized mice (Köhler \& Milstein 1975). Hybridoma technology emerged rapidly as a powerful method to identify novel cell surface markers (Williams et al. 1977). Immunophenotyping with MAbs raised to cell surface markers defined the differentiation status of hematopoietic cells and became the basis for the "clustering of differentiation' or CD classification (Bernard \& Boumsell 1984). Immunophenotyping of hematopoietic cells and hematologic malignancies is commonly performed by FACS analysis, a technique that can detect and quantify antigen expression on the cell surface (Table 2). FACS analysis revealed that some CD antigens commonly expressed on hematopoietic cells are also expressed on hematologic tumors. CD20, for instance, is a B cell lineage marker expressed on $>90 \%$ B-cell non-
Hodgkin's lymphomas and is the target for Rituxan, Zevalin and Bexxar (Table 1).

Hybridoma development for antigen discovery typically includes a differential screen to identify antigens that are highly expressed on tumor cells and sparingly expressed, ideally absent, on non-tumor cells. Screening for cell surface antigens can be carried out using FACS analysis, antibody-cell capture, or fluorometric microvolume assay technology (FMAT). FMAT devices automate microtiter plate reading and handling, thereby facilitating high throughput screening of cell-binding or killing activities in hybridoma wells (Miraglia et al. 1999).

Dominant epitopes can skew the repertoire of hybridomas and limit the diversity of antigens detected. This problem is potentially exacerbated by the weak immunogenicity of some tumor antigens. The impact of dominant epitopes can be minimized by using a subtractive immunization approach (Hooper et al. 2003, Zijlstra et al. 2003) or by incorporating a highly selective screen.

Limitations notwithstanding, hybridoma technology has historically been the most widely used method for tumor antigen discovery. Indeed, many antigens currently being targeted by antibodies in oncology clinical trials (Table 1) were first identified using MAbs, including sialyl Lewis $^{\mathrm{Y}}$ (Hellström et al. 1990) and prostate-specific membrane antigen (PSMA) (Israeli et al. 1993).

\section{Transgenic mice}

Human MAbs can be generated following immunization of transgenic mice that contain human immunoglobulin sequences (Fishwild et al. 1996, Mendez et al. 1997, Tomizuka et al. 2000) (Table 2). Transgenic mice offer a powerful way to generate human antibodies to validated targets for clinical development that have low risk for immunogenicity in man (Davis et al. 2004), thereby obviating the need for humanization of murine MAbs. This benefit of using transgenic over non-transgenic mice for target discovery should be balanced against several downsides (weaker immune response, more effort to generate large panels of antibodies, and high technology access cost) plus the very small proportion of reagent MAbs generated that might ultimately be deemed worthy of preclinical development.

\section{Human hybridomas}

Immortalizing B-cells from cancer patients has been undertaken to develop human hybridomas against cancer antigens. Preparing human hybridomas from cancer patients is advantageous because it provides a direct report on the immune response to the tumor without introducing a biased or cross-species immunization strategy. Moreover such MAbs have a low risk for 
immunogenicity in man, as they are human, and often have few or no somatic mutations (Brändlein et al. 2003b). An intriguing complication is that most, if not all, tumor reactive antibodies isolated from cancer patients are IgMs (Vollmers \& Brändlein 2002), necessitating either isotype switching or molecular reconfiguration to an $\mathrm{IgG}$ (Pancook et al. 2001) to facilitate preclinical and clinical development. Several tumor-selective IgMs from cancer patients have been used to identify their cognate antigens including SC-1 (Hensel et al. 1999) and PAM-1 (Brändlein et al. 2003a). SC-1 binds to a tumor-associated glycoform of CD55 (decay-accelerating factor) that is preferentially expressed on diffuse and intestinal gastric cancer cells and induces apoptosis (Hensel et al. 1999). PAM-1, which was isolated from a patient with stomach carcinoma, binds to a variant of cysteine-rich fibroblast growth factor receptor 1 that is expressed on the surface of many epithelial tumors.

\section{Antibody phage libraries}

The use of phage display libraries offers potentially the most direct route to tumor antigens amenable to antibody targeting, by allowing direct selection of antibodies that bind to tumor cells and counter selection against nontumor cell binding (Cai \& Garen 1995, Ridgway et al. 1999). Moreover, the use of large ( $\geq 10^{9}$ member) naïve antibody phage libraries provides a highly diverse repertoire that is anticipated to allow more comprehensive sampling of the epitope space on the surface of tumor cells than previously possible with other technologies (Liu et al. 2004).

Unfortunately, direct cell selection with phage libraries to identify new tumor antigens has been significantly stymied by non-specific binding of phage to cell surfaces and the selection of dominant antibody clones (Ridgway et al. 1999, Hoogenboom 2002). A significant advance in antibody phage library selections on cells is the use of polyvalent phage and the selection for internalizing phage (Poul et al. 2000). Non-specifically bound phage is stripped from the cell surface prior to recovering the specifically internalized phage. Recently this approach has been used to isolate $>90$ antibodies from a large naïve phage library that bind to prostate cancer cells but sparingly to non-tumor cells (Liu et al. 2004). Such antibodies seem particularly well suited for conjugation to cytotoxic drugs (Payne 2003) or in the construction of immunoliposomes (Nielsen et al. 2002).

\section{Recombinant antibody production from single antigen-selected lymphocytes}

Two methods for producing monoclonal antibodies from a single antibody-producing cell have been described (Lagerkvist et al. 1995, Babcook et al. 1996). Single antibody-producing cells are identified and selected using either antigen-coated magnetic beads (Lagerkvist et al. 1995) or micromanipulation of antigen-binding cells detected with the hemolytic plaque assay (Babcook et al. 1996). Once the desirable antibody-producing cell is isolated, PCR-based cloning is used to amplify the $\mathrm{V}_{\mathrm{L}}$ and $\mathrm{V}_{\mathrm{H}}$ sequences defining the specificity of the antibody. A major advantage of this methodology is that it can identify a rare antibody-forming cell with desirable antigen-binding characteristics. Furthermore, since this methodology retrieves antibody activity through cloning of immunoglobulin sequences, it is amenable to generating antibodies from multiple species, including humans. However, a potential challenge is that PCR-based amplification becomes increasingly complex with rodent and human immunoglobulin sequences. In addition, recombinant antibody production is more time-consuming and onerous than MAb production from hybridoma cell lines.

\section{Target validation}

The number of tumor-associated targets that are identified and advanced to the validation stage is highly dependent upon the scale and methodology of the identification process including the selection criteria. Commonly, one might obtain tens to a few hundred targets that satisfy minimal criteria for tumor association. Pragmatically, the stringency of selection criteria can be increased, if need be, to identify a smaller number of lead targets that match available capacity to validate them.

\section{Plasma membrane localization}

A critical early validation step is to confirm that a target of interest is localized to the plasma membrane and has extracellular determinants amenable to antibody targeting. Based on the gene sequence of novel targets identified through genomic or transcriptomic techniques, subcellular localization patterns for the putative protein products can be predicted using software such as PSORT II (Horton \& Nakai 1997). This program searches for motifs associated with protein sorting and reports on the probability for the protein to be localized to candidate sites including the plasma membrane. Another program, ТМНMM 2.0, predicts the number of transmembrane helices in a protein (Sonnhammer et al. 1998), correctly in $97-98 \%$ of cases (Krogh et al. 2001). Membrane and secreted proteins can also be identified using Gene Ontology Consortium (GO) classifications associated with RefSeq genes (Egland et al. 2003). Bioinformatic predictions of plasma membrane association are valuable but require experimental confirmation. 
FACS (Table 2) using a fluorescently labeled antitarget antibody is the most commonly used method for assessing the presence of an epitope on the exterior surface of cells required for antibody targeting. Genetically fusing the gene encoding the target with an epitope tag obviates the need for an antigen-specific antibody, albeit with a minor risk of altering localization. Following transient mammalian expression of the target fusion construct, FACS is then performed with a fluorescently labeled antitag antibody. Alternatively, the target gene can be fused to a fluorescent tag such as green (Egland et al. 2003) or auto- (Adam et al. 2003) fluorescent protein. Following transient expression, the fluorescent product is localized by confocal fluorescence microscopy. A major drawback of fluorescent protein tagging is that it may indicate plasma membrane association but it does not show definitively that the target is accessible to an antibody on the outside of the cell.

Beyond confirming the presence of a target on the surface of cells, FACS is frequently used to screen tumor cell lines for antigen expression prior to in vitro assays. Several assays have been developed to quantitatively measure protein levels of antigens including estrogen and progesterone receptors (Gritzapis et al. 2003), Fc receptors (Christensen \& Leslie 1990) and CD antigens (Barten et al. 2001). Quantitative FACS analysis can provide data on antigen density required for validation of antibody anti-tumor activity.

\section{Target expression profiling}

After establishing that a target has determinants on the outside of tumor cells, the next major step in developing anti-cancer antibodies is expression profiling of the target antigen in tumor and non-tumor, minimally at the protein level and commonly also at the mRNA level. Expression profiling with human tissue is an obligatory step in target validation that is sometimes superseded by profiling using tumor and non-tumor cell lines. A major caveat of mRNA expression profiling is that a statistically significant correlation between protein and mRNA expression in tumor samples is not common - $20 \%$ of genes and proteins in the largest study to date (Chen et al. 2002a). Thus, for a target of interest, it is critical to evaluate the concordance between mRNA and protein levels. For antibody-based methods of target identification the validation of protein expression is accomplished, in part, during the screening and selection process.

\section{mRNA expression profiling}

Many techniques are available for mRNA expression profiling in clinical samples including microarrays, SAGE, quantitative real-time PCR (QPCR), cDNA hybridizations using multiple tissue expression arrays/cancer profiling arrays, and RNA in situ hybridizations using frozen tissue samples (Table 2). In situ hybridization is a low throughput technique suitable only for target validation, whereas most other methods have sufficient throughput to have gained significant usage both as discovery and also validation tools.

SAGE (Velculescu et al. 1995) utilizes 14-mer tags for each cDNA that are concatemerized and sequenced to quantify the abundance of transcripts. Lengthening the tag length to 21-mer, so-called LongSAGE, has greatly reduced the ambiguity in identifying transcripts due to short tag size (Saha et al. 2002). SAGE experiments involve sequencing of up to 105 tags and are best suited to facilities with high throughput sequencing capability. The results from SAGE experiments, even from different laboratories, are readily compared by data normalization using the number of specific tags sequenced per million total tags sequenced. This portability of SAGE data has been capitalized upon by the National Cancer Institute funded Cancer Genome Anatomy Project, with the largest public data database of archived SAGE tag counts and an excellent online query tool (Lash et al. 2000, Boon et al. 2002). SAGE tags can efficiently identify novel transcripts or genes in the genome as well as provide data on relative expression of the target gene in normal and tumor cells. In contrast, exon splice variants commonly with identical $3^{\prime}$ ends are transparent to SAGE technology. SAGE expression profiling on normal and tumor tissue may help focus IHC analysis on particular organs and/or tumor types. SAGE has identified novel ovarian cancer-specific transcripts that were subsequently characterized by northern blot analysis and real time RT-PCR (Rangel et al. 2003).

QPCR is a commonly and successfully used method to corroborate expression profiles of individual genes identified by other methods. For example, genes overexpressed in small cell lung carcinoma identified by microarray expression profiling were confirmed by QPCR analysis (Bangur et al. 2002). The signal amplification intrinsic to QPCR provides exquisite sensitivity and a wide dynamic range that minimizes the need for serial dilution of samples. QPCR is a powerful tool for validation of mRNA profiles in that it provides accurate and reproducible quantification of nucleic acid and is readily amenable to automation to increase throughput. The availability of software has made the design of necessary QPCR probes simpler and more robust.

\section{Antigen expression profiling}

Evaluation of antigen expression on the surface of tumor and normal cells in human tissue samples is critical to the assessment of antigen suitability for antibody targeting. Moreover, antigen expression profiling may provide a 
critical diagnostic step for patient selection for targeted therapy, as is the case for HER2 (Ross et al. 2003b).

Immunohistochemistry analysis is the most common and effective way of expression profiling antigens that is economical with limited clinical samples (Table 2). IHC involves three major and inter-related choices: recombinant protein or synthetic peptides as an immunogen, rabbit polyclonal antibodies (PAbs) or murine MAbs for antibody generation, and fresh frozen or formalin-fixed paraffin-embedded (FFPE) tissue (Goding 1996).

Antibodies, if none are available, are generated using recombinant antigen or more commonly synthetic peptides as immunogens. The synthetic peptides are designed to match portions of the extracellular domains of the target antigen that are most distinct from other known proteins. Antibodies to short peptides are likely to detect formalindenatured antigen, but may have higher risk for crossreactivity than antibodies to recombinant antigen, and therefore should be validated for specificity to the antigen by western blot analysis.

Rabbit PAbs are more rapidly generated than murine MAbs, making them the more common choice for early target validation experiments. Another advantage of PAbs over MAbs is that they recognize multiple antigenic determinants, allowing for a greater chance of detecting epitopes preserved through chemical fixation and paraffin embedding (Hoffstrom \& Wayner 1994). However, if a $\mathrm{MAb}$ is available that is suitable for profiling of protein by IHC using FFPE tissue this will likely be preferred over a PAb because of higher specificity and affinity. IHC staining can be performed using pooled MAbs when multiple MAbs are available to distinct epitopes of the target antigen (Ziai et al. 1987). Such combinations of MAbs have been shown to increase the sensitivity of IHC without changing the percentage of stained cells.

The main advantages of FFPE tissues over fresh frozen samples for IHC are that they are commonly available in much larger numbers and retain better tissue morphology. A limitation of FFPE tissue for IHC is the potential need to search for an antigen-retrieval step to allow the primary antibody to bind antigen, with no guarantee of success (Shi et al. 2001). In contrast, fresh frozen tissue typically retains high immunoreactivity and is used for IHC when available antibodies recognize native but not formalin-denatured antigen. Analysis of large numbers of human tissues for antigen expression is a critical step for target validation and was a major bottleneck until the advent of tissue microarrays (TMAs, Table 2).

TMAs are a major advance in target validation in that they allow in situ profiling of protein, mRNA or DNA on hundreds of samples in parallel on a single slide. TMAs are constructed by acquiring cylindrical cores from either
FFPE or frozen tissue specimens and arraying them at high density into a recipient block (Kallioniemi et al. 2001). Numerous TMA formats are commercially available including normal tissue arrays, cancer survey panels, and tumor specific collections with up to 1000 samples per slide. 'Large-section' IHC analysis and single tissue punch TMA results typically agree closely and the level of concordance may be increased by adding a few additional tissue punches to TMA (Camp et al. 2000, Rubin et al. 2002). In most instances, the high degree of standardization achieved using TMA more than compensates for minor limitations associated with the minute tissue sample size (Sauter et al. 2003).

IHC for target validation is conveniently undertaken stepwise using TMA. First, antigen expression is analyzed in a normal tissue panel to identify candidates with sparing or no staining of vital organs, and which lack major antigen sinks in other normal tissue. Secondly, prevalence and level of antigen expression in different tumor types are surveyed rapidly using common cancer panel arrays that include normal tissue counterparts from the same patient. Thirdly, the number of samples for positive tumor types is expanded to power the statistics of staining incidence. Minimally, advanced stage disease samples are analyzed to reflect the potential patient population accessible to an early stage experimental drug. More preferably 'progression TMAs' are used to assess changes in antigen expression at different stages of disease. Loss of expression with disease advancement and metastasis occurs for some antigens (al-Tubuly et al. 1996) and bodes poorly for antibody targeting. Additional analysis of normal tissue from different tissues and more individuals is advisable for antigens judged promising after initial TMA steps.

TMA of tumor specimens linked to clinical follow-up data, so called 'prognosis TMA', permits correlation of antigen expression and patient outcome. Prognosis TMA has been used to probe the association of HER2 and EGFR overexpression with patient survival in breast cancer (Sauter et al. 2003). Heterogeneity between primary tumors and their metastases can be analyzed by using a 'metastasis TMA' as exemplified by a study of HER2 status of primary and metastatic breast cancers (Simon et al. 2001). In situ hybridization of mRNA using TMA is a valuable way to corroborate IHC results.

Key advantages of TMA technology over conventional IHC include much greater throughput, cost efficiency, and the standardization inherent in the simultaneous analysis of up to a thousand samples per slide. Critical to TMA success has been the quantification and automated acquisition of data plus the development of sophisticated software for data analysis and archiving. Public domain TMA software is anticipated to facilitate 
the analysis and exchange of large TMA data sets (Berman et al. 2003). Several commercial automated TMA analysis systems use common IHC or fluorescent dyes that provide a greater dynamic range than do peroxidase-based systems (Camp et al. 2002, Haedicke et al. 2003).

\section{Functional target validation}

Defining the function of a target antigen is desirable, but is not a prerequisite for successful antibody targeting. Readers are directed to excellent recent reviews describing the plethora of alternative functional validation techniques that include RNA interference (RNAi) (Boese et al. 2003, Lavery \& King 2003), antisense (Kurreck 2003, Crooke 2004), ribozymes (Castanotto et al. 2002, Kashani-Sabet 2002), gene knock outs, transgenic animals (Tornell \& Snaith 2002), viral transduction, and chemical genomics (Jung et al. 2003, Sehgal 2003). RNA interference (Fig. 1) is one of the most popular of these techniques for studying gene function, and has the potential to streamline some aspects of target validation (Boese et al. 2003, Lavery \& King 2003). RNAi is the mechanism of post-transcriptional gene silencing using small RNAs naturally created from double stranded precursors by RNase III-like activity of the enzyme, Dicer (Bernstein et al. 2001, Hutvagner et al. 2001, Knight \& Bass 2001). RNAi technology typically lowers the target transcript level substantially without eliminating it completely. An altered phenotype often provides significant clues as to gene function, whereas an unaltered phenotype is hard to interpret because of the possibility of residual mRNA maintaining function.

\section{Therapeutic antibody generation}

Validated antigens judged potentially suitable for antibody targeting are then advanced to the next stage, namely, antibody production and in vitro and then in vivo screening for anti-tumor activities (Fig. 1). Unfortunately, there is a dearth of convincingly validated surface antigens that is compounded by the scarcity of so-called 'naked' antibodies with robust anti-tumor activity. Fortunately, the potency of anti-cancer antibodies can be improved in numerous ways including arming with potent drugs (Payne 2003) or radionuclides (Goldenberg 2003). These arming technologies have been validated by the regulatory approval of the antibody drugs, Mylotarg, Zevalin, and Bexxar, conjugated with the drug calicheamicin, and the radionuclides ${ }^{90} \mathrm{Y}$ and ${ }^{131} \mathrm{I}$, respectively (Table 1). Antibody enhancement strategies have been reviewed extensively elsewhere (Carter 2001, Milenic 2002, Presta 2002, Glennie \& van de Winkel 2003, Ross et al. 2003a) and are covered here only to the extent that they impact the identification of a clinical lead antibody with potent in vivo anti-tumor activity. Subsequent antibody optimization, e.g. affinity maturation, to generate an antibody clinical candidate is beyond the scope of this target-centric review.

\section{In vitro screening of antibodies for anti-tumor activity}

Naked antibodies in clinical trials in oncology exhibit several different kinds of anti-tumor activity in vitro and in vivo (Carter 2001, Milenic 2002, Glennie \& van de Winkel 2003, Ludwig et al. 2003) including inhibition of growth, invasion, metastasis or angiogenesis, sensitization to chemotherapy or radiotherapy, induction of apoptosis, growth factor antagonism, and secondary immune functions such as antibody-dependent cellular cytotoxicity or complement-dependent cytotoxicity (see Table 3 for representative examples). Whilst the biological complexity of human tumors cannot be recapitulated in vitro, it is both feasible and desirable to screen antibody panels for many different types of anti-tumor activity.

Numerous assays are available to assess in vitro antitumor activity including $\left[{ }^{3} \mathrm{H}\right]$-thymidine incorporation to assess new DNA synthesis and metabolic dye staining to evaluate the number of viable cells following a cell proliferation assay. Screening of 'naked' antibodies provides a good initial strategy for identifying clinical lead candidates that offers potentially the simplest preclinical and clinical development path. Multiple antigen-positive tumor cell lines should be screened to identify antibodies, such as the MAb 4D5 parent of Herceptin, that have anti-tumor activity on $<50 \%$ of antigen-positive cell lines (Lewis et al. 1993). Tumor cell lines that are antigen negative can also be stably transfected and clones expressing the antigen at different levels can be selected for use in both in vitro and in vivo assays. For example, stable transfectants of $\mathrm{CHO}, \mathrm{PC} 3$, MCF7.Her2 and HCT116 cell lines expressing PSCA were generated and compared with parental lines in response to an anti-PSCA immunoconjugate for in vitro cytotoxicity assay and antitumor efficacy (Ross et al. 2002). This approach provides a model system to address the antigen density requirement and a negative control cell line with similar genetic background.

Biological knowledge of a target antigen can sometimes usefully guide the design of anti-tumor activity assays as evidenced by antibodies to EGFR. Erbitux, previously known as $\mathrm{C} 225$, blocks binding of EGF and transforming growth factor $\alpha(\mathrm{TGF}-\alpha)$ ligands to EGFR, inhibits receptor tyrosine kinase activation by these ligands, and inhibits the growth of EGFR-positive human tumor xenografts in nude mice (Mendelsohn 2000). Erbitux is approved for the treatment of 
Endocrine-Related Cancer (2004) 11 659-687

Table 3 Anti-tumor activities of naked antibodies

\begin{tabular}{|c|c|}
\hline Tumor activities in vitro and in vivo & Representative clinical examples ${ }^{1}$ \\
\hline \multicolumn{2}{|l|}{ Growth inhibition } \\
\hline Cell cycle arrest & Herceptin, Erbitux \\
\hline \multicolumn{2}{|l|}{ Sensitization to other agents } \\
\hline Chemotherapy & Herceptin, Rituxan, Erbitux \\
\hline Radiotherapy & Herceptin, Erbitux \\
\hline \multicolumn{2}{|l|}{ Apoptosis } \\
\hline Activation of proapoptotic pathway & Rituxan \\
\hline Death receptor activation & anti-Trail-R1, anti-Trail-R2 agonist antibodies \\
\hline Inhibition of anti-apoptotic pathway & \\
\hline Growth factor antagonism & Erbitux, Omnitarg, ABX-EGF, HuMax-EGFr \\
\hline \multicolumn{2}{|l|}{ Secondary immune functions } \\
\hline Antibody dependent cellular cytotoxicity & Herceptin, Rituxan, Erbitux, Campath-1H, HuMax-CD20, \\
\hline Complement dependent cytotoxicity & Rituxan, Campath-1H, HuMax-CD20, \\
\hline \multicolumn{2}{|l|}{ Anti-angiogenic } \\
\hline Angiogenic ligand or receptor antagonist & Avastin \\
\hline Indirect & Herceptin, Erbitux \\
\hline Inhibition of invasion/ metastasis & Erbitux \\
\hline
\end{tabular}

${ }^{1}$ Sources: ABX-EGF (E7.6.3 (Yang et al. 1999, Foon et al. 2004)); anti-Trail-R1, anti-Trail-R2; www.cambridgeantibody.com; Avastin (Ferrara 2002, Salgaller 2003); Campath-1H (Schulz et al. 2000); Erbitux (C225 (Mendelsohn 2000)); Herceptin (Sliwkowski et al. 1999, Baselga et al. 2001); HuMax-CD20 and HuMax-EGFR (Glennie \& van de Winkel 2003); Omnitarg (rhuMAb2C4 (Agus et al. 2002, Mendoza et al. 2002)); Rituxan (Cerny et al. 2002, Maloney et al. 2002). See also: Carter (2001), Milenic (2002), Ludwig et al. (2003).

EGFR-positive metastatic colorectal cancer (Table 1). Subsequent to many Erbitux studies, a human anti-EGFR MAb, E7.6.3, was reported that blocks binding of both EGF and TGF- $\alpha$ to various EGFR-expressing human tumor cell lines and abolishes ligand-dependent cell proliferation (Yang et al. 1999). MAb E7.6.3, now known as ABX-EGF, is currently in phase III clinical trials for colorectal cancer (Table 1).

For antigens with a paucity of biological understanding, it may still be possible to identify antibodies with anti-tumor activity and develop them into therapeutics, as illustrated by Herceptin. MAb 4D5 was chosen from a small panel of anti-HER2 antibodies as having the most potent spectrum of in vitro growthinhibitory activity across multiple tumor cell lines (Hudziak et al. 1989, Fendly et al. 1990, Lewis et al. 1993). MAb 4D5 was subsequently humanized (Carter et al. 1992) and ultimately developed as Herceptin (Carter et al. 2000). Years later this panel of anti-HER2 MAb (Fendly et al. 1990) was rescreened using new-found knowledge of two additional EGFR receptor family members, HER3 and HER4, plus numerous cognate ligands. MAb 2C4, unlike Herceptin, blocks heterodimerization of HER2 with HER3 induced by the ligand, heregulin (Agus et al. 2002). MAb 2C4 inhibits the growth of tumor cells induced by heregulin (Agus et al. 2002). A humanized version of MAb 2C4, Omnitarg, is in multiple phase II clinical trials (Table 1).

\section{Recruiting and enhancing anti-tumor activities}

If MAbs are identified with only modest anti-tumor activity it is both feasible and desirable to screen them using methods to recruit or enhance activity. Screening MAbs in combination with chemotherapy is strongly recommended as many antibodies, including Herceptin (Slamon \& Pegram 2001), Rituxan (Demidem et al. 1997) and Erbitux (Mendelsohn 2000) show additive or synergistic anti-tumor activity in combination with chemotherapy. Moreover, combining drugs in oncology is a widely adopted paradigm. Indeed, combining antibodies with chemotherapy can sometimes improve the anti-tumor response rate or response duration as evidenced by Herceptin (Slamon et al. 2001) and Rituxan (Herold et al. 2003). The choice of chemotherapeutic agents for antibody combination in preclinical screens is usefully guided by a consideration of common chemotherapy regimens utilized in potential clinical settings for the antibody drug.

Antibody drug conjugates commonly, but not invariably, have much greater in vitro and in vivo antitumor potency than their corresponding naked parent antibodies (Liu et al. 1996, Ross et al. 2002, Bhaskar et al. 2003, Doronina et al. 2003, Mao et al. 2004), thereby potentially extending the range of surface antigens amenable to antibody targeting in oncology. However, the benefits of drug conjugation must be weighed against the challenges: need for an internalizing antibody, more 
complex preclinical and clinical development, a possible need for a closer to ideal antigen expression profile and increased risk of toxicity in patients.

In screening MAbs for their suitability as drug conjugates it is often impractical to conjugate each individual antibody. However, it is feasible to screen in the presence of a drug conjugate of a cross-linking antibody such as an anti-light chain MAb. Importantly, the behavior of a secondary antibody drug conjugate is often predictive of the behavior of a primary antibody drug conjugate (Klussman et al. 2004).

\section{In vivo screening of antibodies for anti-tumor activity}

Ideally, a large panel of MAbs is screened for anti-tumor activity in a battery of different in vitro assays. If possible, one selects the 'best-in-class' for each kind of anti-tumor activity, compares their anti-tumor activities in vivo, and selects a clinical lead candidate. Minimally, one needs a single antibody-based agent with robust in vitro antitumor activity to warrant in vivo evaluation. Commonly, human tumor cell lines (or explants) are xenografted into immune-compromised mice, such as nude or SCID, and allowed to establish. Tumors are treated with test or control agents and their size followed over a few weeks to months. If necessary, the stringency of the model can be increased by allowing the tumors to grow larger (commonly $100-500 \mathrm{~mm}^{3}$ ), or by reducing the dose or the number of doses.

Complete responses (i.e. no detectable tumor remaining) or cures (i.e. no tumor regrowth following a complete response) under stringent conditions and in multiple models would likely provide sufficient impetus to select a lead candidate for further optimization into a clinical candidate. Whilst such a high hurdle for efficacy can sometimes be met, e.g. using antibody drug conjugates (Liu et al. 1996, Ross et al. 2002, Bhaskar et al. 2003, Doronina et al. 2003, Mao et al. 2004), it does not necessarily predicate significant benefit to patients within acceptable toxicities. Another limitation of in vivo tumor models is that they are unavoidably imperfect mimics of human disease. Despite these limitations, in vivo tumor models are critical to the anti-cancer drug development process, providing the means to filter numerous test agents with potent in vitro anti-tumor activity down to a small, and hopefully more promising, subset worthy of further preclinical and clinical development.

\section{Conclusions and perspectives}

The search for surface antigens on tumor cells amenable to antibody targeting commonly begins with a hunt for differences between tumor and non-tumor cells at the
DNA, mRNA, protein or antibody reactivity levels. Thus far, no single approach or even combination of methods has emerged as the preferred way to identify surface antigens suitable for targeting in oncology. Genomics, specifically the availability of the human genome sequence (Lander et al. 2001, Venter et al. 2001), has empowered more direct means of target identification, e.g. by expanding protein databases and enabling the mapping of novel cancer-associated genes. Transcriptomic methods have proved particularly powerful in defining gene expression signatures for cancer diagnosis or prognosis, but less so to date for the identification of potential antibody targets. The most promising application of transcriptomics, from an antibody target perspective, is the discovery of tumor-specific splice variants. Low prevalence of antigens, including splice variants, is a potentially limiting factor in their exploitation for commercial antibody drug development. Proteomic methods are appealing in that they allow a direct search for cell surface features that distinguish tumor cells from their normal counterparts. Rapid progress in expanding the throughput and capabilities of mass spectrometry bode well for proteomic identification of new tumorassociated antigens.

Historically, hybridoma technology has been the most successful tool for tumor antigen identification, but the point of diminishing returns appears to have been reached for this particular application. Large libraries of antibody phage offer the most direct and potentially comprehensive method for identifying antibodies that bind to tumor cells and sparingly to non-tumor cells. Many technical obstacles have been overcome to allow successful application of phage display technology to tumor cell panning (Liu et al. 2004). However, subsequent identification of cognate antigens remains a significant bottleneck for this, and other, antibody-based approaches.

Ideally, target validation includes profiling the expression of antigens across numerous normal tissues and tumor types. For the most promising candidates it is desirable to expand the survey of positive tumors to include large numbers of specimens at each stage of disease to provide robust estimates of the extent and prevalence of antigen expression. Such extensive expression profiling has only recently become feasible with the advent of so called tissue microarrays (TMA, Table 2) that allow in situ profiling of protein, mRNA or DNA on hundreds of samples in parallel.

Currently, there is a dearth of convincingly validated surface antigens that is compounded by the scarcity of so-called 'naked' antibodies with robust anti-tumor activity. Fortunately, the potency of anti-cancer antibodies can be improved in numerous ways (Carter 2001, Milenic 2002, Presta 2002, Glennie \& van de Winkel 2003, 
Ross et al. 2003a). Thus, for validated targets there is often a compelling rationale to enhance the activity of corresponding antibodies for human therapy and a growing box of tools with which to do so. Our hope and expectation is that the marriage of target identification with antibody enhancement technologies will ultimately translate into new and improved therapies for cancer patients.

\section{Acknowledgements}

The broad scope and limited space for this review has obliged us to pick representative examples throughout. We apologize to numerous investigators whose excellent work we have not been able to cite. The authors are employed by Seattle Genetics, a company that discovers and develops monoclonal antibody-based therapeutics, including antibody drug conjugates, to treat cancer and immunologic diseases.

\section{References}

Adam PJ, Boyd R, Tyson KL, Fletcher GC, Stamps A, Hudson L, Poyser HR, Redpath N, Griffiths M, Steers G et al. 2003 Comprehensive proteomic analysis of breast cancer cell membranes reveals unique proteins with potential roles in clinical cancer. Journal of Biological Chemistry 278 6482-6489.

Agus DB, Akita RW, Fox WD, Lewis GD, Higgins B, Pisacane PI, Lofgren JA, Tindell C, Evans DP, Maiese K et al. 2002 Targeting ligand-activated ErbB2 signaling inhibits breast and prostate tumor growth. Cancer Cell 2 127-137.

Alizadeh AA, Eisen MB, Davis RE, Ma C, Lossos IS, Rosenwald A, Boldrick JC, Sabet H, Tran T, Yu X et al. 2000 Distinct types of diffuse large B-cell lymphoma identified by gene expression profiling. Nature 403 503-511.

Baak JP, Path FR, Hermsen MA, Meijer G, Schmidt J \& Janssen EA 2003 Genomics and proteomics in cancer. European Journal of Cancer 39 1199-1215.

Babcook JS, Leslie KB, Olsen OA, Salmon RA \& Schrader JW 1996 A novel strategy for generating monoclonal antibodies from single, isolated lymphocytes producing antibodies of defined specificities. PNAS 93 7843-7848.

Bangur CS, Switzer A, Fan L, Marton MJ, Meyer MR \& Wang T 2002 Identification of genes over-expressed in small cell lung carcinoma using suppression subtractive hybridization and cDNA microarray expression analysis. Oncogene 21 3814-3825.

Barratt-Boyes SM 1996 Making the most of mucin: a novel target for tumor immunotherapy. Cancer Immunology Immunotherapy 43 142-151.

Barten MJ, Gummert JF, van Gelder T, Shorthouse R \& Morris RE 2001 Flow cytometric quantitation of calcium-dependent and -independent mitogen-stimulation of $\mathrm{T}$ cell functions in whole blood: inhibition by immunosuppressive drugs in vitro. Journal of Immunological Methods 253 95-112.
Baselga J, Tripathy D, Mendelsohn J, Baughman S, Benz CC, Dantis L, Sklarin NT, Seidman AD, Hudis CA, Moore J et al. 1996 Phase II study of weekly intravenous recombinant humanized anti-p $185^{\mathrm{HER} 2}$ monoclonal antibody in patients with HER2/neu-overexpressing metastatic breast cancer. Journal of Clinical Oncology 14 737-744.

Baselga J, Albanell J, Molina MA \& Arribas J 2001 Mechanism of action of trastuzumab and scientific update. Seminars in Oncology 28 4-11.

Becker KF, Atkinson MJ, Reich U, Becker I, Nekarda H, Siewert JR \& Hofler H 1994 E-cadherin gene mutations provide clues to diffuse type gastric carcinomas. Cancer Research $\mathbf{5 4}$ 3845-3852.

Becker KF, Kremmer E, Eulitz M, Becker I, Handschuh G, Schuhmacher C, Muller W, Gabbert HE, Ochiai A, Hirohashi S et al. 1999 Analysis of E-cadherin in diffuse-type gastric cancer using a mutation-specific monoclonal antibody. American Journal of Pathology 155 1803-1809.

Becker KF, Kremmer E, Eulitz M, Schulz S, Mages J, Handschuh G, Wheelock MJ, Cleton-Jansen AM, Hofler H \& Becker I 2002 Functional allelic loss detected at the protein level in archival human tumours using allele-specific E-cadherin monoclonal antibodies. Journal of Pathology 197 567-574.

Beer DG, Kardia SL, Huang CC, Giordano TJ, Levin AM, Misek DE, Lin L, Chen G, Gharib TG, Thomas DG et al. 2002 Gene-expression profiles predict survival of patients with lung adenocarcinoma. Nature Medicine 8 816-824.

Berman JJ, Edgerton ME \& Friedman BA 2003 The tissue microarray data exchange specification: a community-based, open source tool for sharing tissue microarray data. BioMed Central Medical Informatics and Decision Making 39.

Bernard A \& Boumsell L 1984 The clusters of differentiation (CD) defined by the First International Workshop on Human Leucocyte Differentiation Antigens. Human Immunology 11 $1-10$.

Bernard K, Litman E, Fitzpatrick JL, Shellman YG, Argast G, Polvinen K, Everett AD, Fukasawa K, Norris DA, Ahn NG et al. 2003 Functional proteomic analysis of melanoma progression. Cancer Research 63 6716-6725.

Bernstein E, Caudy AA, Hammond SM \& Hannon GJ 2001 Role for a bidentate ribonuclease in the initiation step of RNA interference. Nature 409 363-366.

Bhaskar V, Law DA, Ibsen E, Breinberg D, Cass KM, DuBridge RB, Evangelista F, Henshall SM, Hevezi P, Miller JC et al. 2003 E-selectin up-regulation allows for targeted drug delivery in prostate cancer. Cancer Research 63 6387-6394.

Boese Q, Scaringe A \& Marshall W 2003 siRNA as a tool for streamlining functional genomic studies. Targets 2 93-100.

Bonner WA, Hulett HR, Sweet RG \& Herzenberg LA 1972 Fluorescence activated cell sorting. Review of Scientific Instruments 43 404-409.

Boon K, Osorio EC, Greenhut SF, Schaefer CF, Shoemaker J, Polyak K, Morin PJ, Buetow KH, Strausberg RL, De Souza SJ et al. 2002 An anatomy of normal and malignant gene expression. PNAS 99 11287-11292.

Bowler LD 2004 Representational difference analysis of cDNA. Methods in Molecular Medicine 94 49-66. 
Braakhuis BJ, Tabor MP, Kummer JA, Leemans CR \& Brakenhoff RH 2003 A genetic explanation of Slaughter's concept of field cancerization: evidence and clinical implications. Cancer Research 63 1727-1730.

Brändlein S, Beyer I, Eck M, Bernhardt W, Hensel F, MüllerHermelink HK \& Vollmers HP 2003a Cysteine-rich fibroblast growth factor receptor 1 , a new marker for precancerous epithelial lesions defined by the human monoclonal antibody PAM-1. Cancer Research 63 2052-2061.

Brändlein S, Pohle T, Ruoff N, Wozniak E, Müller-Hermelink HK \& Vollmers HP 2003b Natural IgM antibodies and immunosurveillance mechanisms against epithelial cancer cells in humans. Cancer Research 63 7995-8005.

Brekke OH \& Sandlie I 2003 Therapeutic antibodies for human diseases at the dawn of the twenty-first century. Nature Reviews Drug Discovery 2 52-62.

Brenner S, Johnson M, Bridgham J, Golda G, Lloyd DH, Johnson D, Luo S, McCurdy S, Foy M, Ewan M et al. 2000 Gene expression analysis by massively parallel signature sequencing (MPSS) on microbead arrays. Nature Biotechnology 18 630-634.

Burgemeister R, Gangnus R, Haar B, Schutze K \& Sauer U 2003 High quality RNA retrieved from samples obtained by using LMPC (laser microdissection and pressure catapulting) technology. Pathology Research and Practice 199 431-436.

Byers RJ, Hoyland JA, Dixon J \& Freemont AJ 2000 Subtractive hybridisation - genetic takeaways and the search for meaning. International Journal of Experimental Pathology $\mathbf{8 1}$ 391-404.

Cai X \& Garen A 1995 Anti-melanoma antibodies from melanoma patients immunized with genetically modified autologous tumor cells: selection of specific antibodies from single-chain Fv fusion phage libraries. PNAS 92 6537-6541.

Camp RL, Charette LA \& Rimm DL 2000 Validation of tissue microarray technology in breast carcinoma. Laboratory Investigation 80 1943-1949.

Camp RL, Chung GG \& Rimm DL 2002 Automated subcellular localization and quantification of protein expression in tissue microarrays. Nature Medicine 8 1323-1327.

Carnemolla B, Balza E, Siri A, Zardi L, Nicotra MR, Bigotti A \& Natali PG 1989 A tumor-associated fibronectin isoform generated by alternative splicing of messenger RNA precursors. Journal of Cell Biology 108 1139-1148.

Carnemolla B, Borsi L, Balza E, Castellani P, Meazza R, Berndt A, Ferrini S, Kosmehl H, Neri D \& Zardi L 2002 Enhancement of the antitumor properties of interleukin-2 by its targeted delivery to the tumor blood vessel extracellular matrix. Blood 99 1659-1665.

Carter P 2001 Improving the efficacy of antibody-based cancer therapies. Nature Reviews Cancer 1 118-129.

Carter P, Presta L, Gorman CM, Ridgway JB, Henner D, Wong WL, Rowland AM, Kotts C, Carver ME \& Shepard HM 1992 Humanization of an anti-p185HER2 antibody for human cancer therapy. PNAS 89 4285-4289.

Carter P, Fendly BM, Lewis GD \& Sliwkowski MX 2000 Development of Herceptin. Breast Disease 11 103-111.

Castanotto D, Li JR, Michienzi A, Langlois MA, Lee NS, Puymirat J \& Rossi JJ 2002 Intracellular ribozyme applications. Biochemical Society Transactions 30 1140-1145.
Celis JE \& Gromov P 2003 Proteomics in translational cancer research: toward an integrated approach. Cancer Cell 3 9-15.

Celis JE, Ostergaard M, Basse B, Celis A, Lauridsen JB, Ratz GP, Andersen I, Hein B, Wolf H, Orntoft TF et al. 1996 Loss of adipocyte-type fatty acid binding protein and other protein biomarkers is associated with progression of human bladder transitional cell carcinomas. Cancer Research 56 4782-4790.

Celis JE, Ostergaard M, Rasmussen HH, Gromov P, Gromova I, Varmark H, Palsdottir H, Magnusson N, Andersen I, Basse B et al. 1999 A comprehensive protein resource for the study of bladder cancer: http://biobase.dk/cgi-bin/celis. Electrophoresis 20 300-309.

Cerny T, Borisch B, Introna M, Johnson P \& Rose AL 2002 Mechanism of action of rituximab. Anticancer Drugs $\mathbf{1 3}$ (Suppl 2) S3-S10.

Chen G, Gharib TG, Huang C-C, Taylor JMG, Misek DE, Kardia SLR, Giordano TJ, Iannettoni MD, Orringer MB, Hanash SM et al. 2002a Discordant protein and mRNA expression in lung adenocarcinomas. Molecular and Cellular Proteomics 1 304-313.

Chen G, Gharib TG, Huang CC, Thomas DG, Shedden KA, Taylor JM, Kardia SL, Misek DE, Giordano TJ, Iannettoni MD et al. $2002 b$ Proteomic analysis of lung adenocarcinoma: identification of a highly expressed set of proteins in tumors Clinical Cancer Research 8 2298-2305.

Christensen J \& Leslie RG 1990 Quantitative measurement of Fc receptor activity on human peripheral blood monocytes and the monocyte-like cell line, U937, by laser flow cytometry. Journal of Immunological Methods 132 211-219.

Cobleigh MA, Vogel CL, Tripathy D, Robert NJ, Scholl S, Fehrenbacher L, Wolter JM, Paton V, Shak S, Lieberman G et al. 1999 Multinational study of the efficacy and safety of humanized anti-HER 2 monoclonal antibody in women who have HER2-overexpressing metastatic breast cancer that has progressed after chemotherapy for metastatic disease. Journal of Clinical Oncology 17 2639-2648.

Correa RG, de Carvalho AF, Pinheiro NA, Simpson AJ \& de Souza SJ 2000 NABC1 (BCAS1): alternative splicing and downregulation in colorectal tumors. Genomics 65 299-302.

Cox JM 2001 Applications of nylon membrane arrays to gene expression analysis. Journal of Immunological Methods $\mathbf{2 5 0}$ $3-13$.

Crombet T, Osorio M, Cruz T, Roca C, del Castillo R, Mon R, Iznaga-Escobar N, Figueredo R, Koropatnick J, Renginfo E et al. 2004 Use of the humanized anti-epidermal growth factor receptor monoclonal antibody h-R3 in combination with radiotherapy in the treatment of locally advanced head and neck cancer patients. Journal of Clinical Oncology 22 1646-1654.

Crooke ST 2004 Progress in antisense technology. Annual Review of Medicine 55 61-95.

Davis CG, Jia XC, Feng X \& Haak-Frendscho M 2004 Production of human antibodies from transgenic mice. Methods in Molecular Biology 248 191-200.

DeGrendele H 2003 The anti-HER2 monoclonal antibody pertuzumab may be effective in androgen-independent prostate cancer. Clinical Prostate Cancer 2 143-145.

Demidem A, Lam T, Alas S, Hariharan K, Hanna N \& Bonavida B 1997 Chimeric anti-CD20 (IDEC-C2B8) monoclonal 
antibody sensitizes a B cell lymphoma cell line to cell killing by cytotoxic drugs. Cancer Biotherapy and

Radiopharmaceuticals 12 177-186.

Di Fiore PP, Pierce JH, Kraus MH, Segatto O, King CR \& Aaronson SA 1987 erbB-2 is a potent oncogene when overexpressed in NIH/3T3 cells. Science 237 178-182.

Diatchenko L, Lau YF, Campbell AP, Chenchik A, Moqadam F, Huang B, Lukyanov S, Lukyanov K, Gurskaya N, Sverdlov ED et al. 1996 Suppression subtractive hybridization: a method for generating differentially regulated or tissue-specific cDNA probes and libraries. PNAS $\mathbf{9 3}$ 6025-6030.

Diaz LK, Zhou X, Welch K, Sahin A \& Gilcrease MZ 2004 Chromogenic in situ hybridization for alpha6beta4 integrin in breast cancer: correlation with protein expression. Journal of Molecular Diagnostics 6 10-15.

Ding C \& Cantor CR 2004 Quantitative analysis of nucleic acids - the last few years of progress. Journal of Biochemistry and Molecular Biology 37 1-10.

Doronina SO, Toki BE, Torgov MY, Mendelsohn BA, Cerveny CG, Chace DF, DeBlanc RL, Gearing RP, Bovee TD, Siegall CB et al. 2003 Development of potent monoclonal antibody auristatin conjugates for cancer therapy. Nature Biotechnology 21 778-784.

Druker BJ 2002 Perspectives on the development of a molecularly targeted agent. Cancer Cell 1 31-36.

Egland KA, Vincent JJ, Strausberg R, Lee B \& Pastan I 2003 Discovery of the breast cancer gene BASE using a molecular approach to enrich for genes encoding membrane and secreted proteins. PNAS 100 1099-1104.

Einfeld DA, Brown JP, Valentine MA, Clark EA \& Ledbetter JA 1988 Molecular cloning of the human B cell CD20 receptor predicts a hydrophobic protein with multiple transmembrane domains. EMBO Journal 7 711-717.

Eltoum IA, Siegal GP \& Frost AR 2002 Microdissection of histologic sections: past, present, and future. Advances in Anatomical Pathology 9 316-322.

Emmert-Buck MR, Bonner RF, Smith PD, Chuaqui RF, Zhuang Z, Goldstein SR, Weiss RA \& Liotta LA 1996 Laser capture microdissection. Science 274 998-1001.

Fendly BM, Winget M, Hudziak RM, Lipari MT, Napier MA \& Ullrich A 1990 Characterization of murine monoclonal antibodies reactive to either the human epidermal growth factor receptor or HER2/neu gene product. Cancer Research 50 1550-1558.

Ferrara N 2002 Role of vascular endothelial growth factor in physiologic and pathologic angiogenesis: therapeutic implications. Seminars in Oncology 29 10-14.

Fishwild DM, O'Donnell SL, Bengoechea T, Hudson DV, Harding F, Bernhard SL, Jones D, Kay RM, Higgins KM, Schramm SR et al. 1996 High avidity human IgGk monoclonal antibodies from a novel strain of minilocus transgenic mice. Nature Biotechnology 14 845-851.

Flory MR, Griffin TJ, Martin D \& Aebersold R 2002 Advances in quantitative proteomics using stable isotope tags. Trends in Biotechnology 20 S23-S29.

Foon KA, Yang XD, Weiner LM, Belldegrun AS, Figlin RA, Crawford J, Rowinsky EK, Dutcher JP, Vogelzang NJ, Gollub J et al. 2004 Preclinical and clinical evaluations of
ABX-EGF, a fully human anti-epidermal growth factor receptor antibody. International Journal of Radiation Oncology Biology Physics 58 984-990.

Ghanekar SA \& Maecker HT 2003 Cytokine flow cytometry: multiparametric approach to immune function analysis. Cytotherapy 5 1-6.

Gilbertson R, Hernan R, Pietsch T, Pinto L, Scotting P, Allibone R, Ellison D, Perry R, Pearson A \& Lunec J 2001 Novel ERBB4 juxtamembrane splice variants are frequently expressed in childhood medulloblastoma. Genes Chromosomes Cancer 31 288-294.

Gilmour LM, Macleod KG, McCaig A, Gullick WJ, Smyth JF \& Langdon SP 2001 Expression of erbB-4/HER-4 growth factor receptor isoforms in ovarian cancer. Cancer Research $\mathbf{6 1}$ 2169-2176.

Glassy MC 1993 Production methods for generating human monoclonal antibodies. Human Antibodies and Hybridomas 4 154-165.

Glennie MJ \& van de Winkel JG 2003 Renaissance of cancer therapeutic antibodies. Drug Discovery Today 8 503-510.

Goding JW 1996 Monoclonal antibodies: principles and practice, vol. San Diego, CA: Academic Press Ltd.

Goldenberg DM 2003 Advancing role of radiolabeled antibodies in the therapy of cancer. Cancer Immunology Immunotherapy 52 281-296.

Golub TR, Slonim DK, Tamayo P, Huard C, Gaasenbeek M, Mesirov JP, Coller H, Loh ML, Downing JR, Caligiuri MA et al. 1999 Molecular classification of cancer: class discovery and class prediction by gene expression monitoring. Science $\mathbf{2 8 6}$ 531-537.

Griffiths AD, Williams SC, Hartley O, Tomlinson IM, Waterhouse P, Crosby WL, Kontermann RE, Jones PT, Low NM, Allison TJ et al. 1994 Isolation of high affinity human antibodies directly from large synthetic repertoires. $E M B O$ Journal 13 3245-3260.

Gritzapis AD, Baxevanis CN, Missitzis I, Katsanou ES, Alexis MN, Yotis J \& Papamichail M 2003 Quantitative fluorescence cytometric measurement of estrogen and progesterone receptors: correlation with the hormone binding assay. Breast Cancer Research and Treatment 80 1-13.

Gu Z, Thomas G, Yamashiro J, Shintaku IP, Dorey F, Raitano A, Witte ON, Said JW, Loda M \& Reiter RE 2000 Prostate stem cell antigen (PSCA) expression increases with high gleason score, advanced stage and bone metastasis in prostate cancer. Oncogene 19 1288-1296.

Gunthert U, Hofmann M, Rudy W, Reber S, Zoller M, Haussmann I, Matzku S, Wenzel A, Ponta H \& Herrlich P 1991 A new variant of glycoprotein CD44 confers metastatic potential to rat carcinoma cells. Cell 65 13-24.

Guo QM 2003 DNA microarray and cancer. Current Opinion in Oncology 15 36-43.

Gygi SP, Han DK, Gingras AC, Sonenberg N \& Aebersold R $1999 a$ Protein analysis by mass spectrometry and sequence database searching: tools for cancer research in the postgenomic era. Electrophoresis 20 310-319.

Gygi SP, Rist B, Gerber SA, Turecek F, Gelb MH \& Aebersold R $1999 b$ Quantitative analysis of complex protein mixtures using isotope-coded affinity tags. Nature Biotechnology 17 994-999. 
Haedicke W, Popper HH, Buck CR \& Zatloukal K 2003 Automated evaluation and normalization of immunohistochemistry on tissue microarrays with a DNA microarray scanner. Biotechniques 35 164-168.

Halin C, Rondini S, Nilsson F, Berndt A, Kosmehl H, Zardi L \& Neri D 2002 Enhancement of the antitumor activity of interleukin-12 by targeted delivery to neovasculature. Nature Biotechnology 20 264-269.

Han DK, Eng J, Zhou H \& Aebersold R 2001 Quantitative profiling of differentiation-induced microsomal proteins using isotope-coded affinity tags and mass spectrometry. Nature Biotechnology 19 946-951.

Hanash S 2003 Disease proteomics. Nature 422 226-232.

Hanash SM, Baier LJ, McCurry L \& Schwartz SA 1986 Lineagerelated polypeptide markers in acute lymphoblastic leukemia detected by two-dimensional gel electrophoresis. PNAS $\mathbf{8 3}$ 807-811.

Hanash SM, Strahler JR, Kuick R, Chu EH \& Nichols D 1988 Identification of a polypeptide associated with the malignant phenotype in acute leukemia. Journal of Biological Chemistry $26312813-12815$.

Hanash SM, Madoz-Gurpide J \& Misek DE 2002 Identification of novel targets for cancer therapy using expression proteomics. Leukemia 16 478-485.

Heider KH, Hofmann M, Hors E, van den Berg F, Ponta H, Herrlich P \& Pals ST 1993 A human homologue of the rat metastasis-associated variant of CD44 is expressed in colorectal carcinomas and adenomatous polyps. Journal of Cell Biology 120 227-233.

Hellström I, Garrigues HJ, Garrigues U \& Hellström KE 1990 Highly tumor-reactive, internalizing, mouse monoclonal antibodies to Le(y)-related cell surface antigens. Cancer Research 50 2183-2190.

Hensel F, Hermann R, Schubert C, Abe N, Schmidt K, Franke A, Shevchenko A, Mann M, Müller-Hermelink HK \& Vollmers HP 1999 Characterization of glycosylphosphatidylinositol-linked molecule CD55/decayaccelerating factor as the receptor for antibody SC-1-induced apoptosis. Cancer Research 59 5299-5306.

Hermeking H 2003 Serial analysis of gene expression and cancer. Current Opinion in Oncology 15 44-49.

Herold M, Dolken G, Fiedler F, Franke A, Freund M, Helbig W \& Pasold R 2003 Randomized phase III study for the treatment of advanced indolent non-Hodgkin's lymphomas (NHL) and mantle cell lymphoma: chemotherapy versus chemotherapy plus rituximab. Annals of Hematology $\mathbf{8 2}$ 77-79.

Herzenberg LA, Parks D, Sahaf B, Perez O \& Roederer M 2002 The history and future of the fluorescence activated cell sorter and flow cytometry: a view from Stanford. Clinical Chemistry 48 1819-1827.

Hoffstrom BG \& Wayner EA 1994 Immunohistochemical techniques to study the extracellular matrix and its receptors. Methods in Enzymology 245 316-346.

Hoogenboom HR 2002 Overview of antibody phage-display technology and its applications. Methods in Molecular Biology 178 1-37.

Hooper JD, Zijlstra A, Aimes RT, Liang H, Claassen GF, Tarin D, Testa JE \& Quigley JP 2003 Subtractive immunization using highly metastatic human tumor cells identifies SIMA135/CDCP1, a $135 \mathrm{kDa}$ cell surface phosphorylated glycoprotein antigen. Oncogene 22 1783-1794.

Horton P \& Nakai K 1997 Better prediction of protein cellular localization sites with the $\mathrm{k}$ nearest neighbors classifier. Proceedings of the International Conference on Intelligent Systems for Molecular Biology 5 147-152.

Hoving S, Gerrits B, Voshol H, Muller D, Roberts RC \& van Oostrum J 2002 Preparative two-dimensional gel electrophoresis at alkaline $\mathrm{pH}$ using narrow range immobilized pH gradients. Proteomics 2 127-134.

Hsu SM, Raine L \& Fanger H 1981 Use of avidin-biotinperoxidase complex $(\mathrm{ABC})$ in immunoperoxidase techniques: a comparison between $\mathrm{ABC}$ and unlabeled antibody (PAP) procedures. Journal of Histochemical Cytochemistry 29 577-580.

Hudziak RM, Schlessinger J \& Ullrich A 1987 Increased expression of the putative growth factor receptor p185HER2 causes transformation and tumorigenesis of NIH $3 \mathrm{~T} 3$ cells. PNAS 84 7159-7163.

Hudziak RM, Lewis GD, Winget M, Fendly BM, Shepard HM \& Ullrich A 1989 p185HER2 monoclonal antibody has antiproliferative effects in vitro and sensitizes human breast tumor cells to tumor necrosis factor. Molecular and Cellular Biology 9 1165-1172.

Hunt DF, Henderson RA, Shabanowitz J, Sakaguchi K, Michel H, Sevilir N, Cox AL, Appella E \& Engelhard VH $1992 a$ Characterization of peptides bound to the class I MHC molecule HLA-A2.1 by mass spectrometry. Science $\mathbf{2 5 5}$ 1261-1263.

Hunt DF, Michel H, Dickinson TA, Shabanowitz J, Cox AL, Sakaguchi K, Appella E, Grey HM \& Sette A $1992 b$ Peptides presented to the immune system by the murine class II major histocompatibility complex molecule I-Ad. Science $\mathbf{2 5 6}$ $1817-1820$.

Hutvagner G, McLachlan J, Pasquinelli AE, Balint E, Tuschl T \& Zamore PD 2001 A cellular function for the RNAinterference enzyme Dicer in the maturation of the let-7 small temporal RNA. Science 293 834-838.

Iacobuzio-Donahue CA, Ashfaq R, Maitra A, Adsay NV, Shen-Ong GL, Berg K, Hollingsworth MA, Cameron JL, Yeo CJ, Kern SE et al. 2003 Highly expressed genes in pancreatic ductal adenocarcinomas: a comprehensive characterization and comparison of the transcription profiles obtained from three major technologies. Cancer Research 63 8614-8622.

Israeli RS, Powell CT, Fair WR \& Heston WD 1993 Molecular cloning of a complementary DNA encoding a prostatespecific membrane antigen. Cancer Research 53 227-230.

Jenkins RE \& Pennington SR 2001 Arrays for protein expression profiling: towards a viable alternative to two-dimensional gel electrophoresis? Proteomics 1 13-29.

Johns TG, Luwor RB, Murone C, Walker F, Weinstock J, Vitali AA, Perera RM, Jungbluth AA, Stockert E, Old LJ et al. 2003 Antitumor efficacy of cytotoxic drugs and the monoclonal antibody 806 is enhanced by the EGF receptor inhibitor AG1478. PNAS 100 15871-15876.

Johnson JM, Castle J, Garrett-Engele P, Kan Z, Loerch PM, Armour CD, Santos R, Schadt EE, Stoughton R \& Shoemaker DD 2003 Genome-wide survey of human 
alternative pre-mRNA splicing with exon junction microarrays. Science 302 2141-2144.

Julius MH, Masuda T \& Herzenberg LA 1972 Demonstration that antigen-binding cells are precursors of antibodyproducing cells after purification with a fluorescence-activated cell sorter. PNAS 69 1934-1938.

Jung M, Kim H \& Kim M 2003 Chemical genomics strategy for the discovery of new anticancer agents. Current Medicinal Chemistry 10 757-762.

Junttila TT, Sundvall M, Maatta JA \& Elenius K 2000 Erbb4 and its isoforms: selective regulation of growth factor responses by naturally occurring receptor variants. Trends in Cardiovascular Medicine 10 304-310.

Kallioniemi OP, Kallioniemi A, Kurisu W, Thor A, Chen LC, Smith HS, Waldman FM, Pinkel D \& Gray JW 1992 ERBB2 amplification in breast cancer analyzed by fluorescence in situ hybridization. PNAS 89 5321-5325.

Kallioniemi OP, Wagner U, Kononen J \& Sauter G 2001 Tissue microarray technology for high-throughput molecular profiling of cancer. Human Molecular Genetics 10 657-662.

Kashani-Sabet M 2002 Ribozyme therapeutics. Journal of Investigative Dermatology Symposium Proceedings 7 76-78.

Kern W, Kohlmann A, Wuchter C, Schnittger S, Schoch C, Mergenthaler S, Ratei R, Ludwig WD, Hiddemann W \& Haferlach T 2003 Correlation of protein expression and gene expression in acute leukemia. Cytometry 55B 29-36.

Klussman K, Mixan BJ, Cerveny CG, Meyer DL, Senter PD \& Wahl AF 2004 Secondary mAb-vcMMAE conjugates are highly sensitive reporters of antibody internalization via the lysosome pathway. Bioconjugate Chemistry 15 765-773.

Knight SW \& Bass BL 2001 A role for the RNase III enzyme DCR-1 in RNA interference and germ line development in Caenorhabditis elegans. Science 293 2269-2271.

Köhler G \& Milstein C 1975 Continuous cultures of fused cells secreting antibody of predefined specificity. Nature $\mathbf{2 5 6}$ 495-497.

Kononen J, Bubendorf L, Kallioniemi A, Barlund M, Schraml P, Leighton S, Torhorst J, Mihatsch MJ, Sauter G \& Kallioniemi OP 1998 Tissue microarrays for high-throughput molecular profiling of tumor specimens. Nature Medicine $\mathbf{4}$ 844-847.

Krogh A, Larsson B, von Heijne G \& Sonnhammer EL 2001 Predicting transmembrane protein topology with a hidden Markov model: application to complete genomes. Journal of Molecular Biology 305 567-580.

Kruse N, Pette M, Toyka K \& Rieckmann P 1997 Quantification of cytokine mRNA expression by RT PCR in samples of previously frozen blood. Journal of Immunological Methods 210 195-203.

Kurreck J 2003 Antisense technologies. Improvement through novel chemical modifications. European Journal of Biochemistry 270 1628-1644.

Lagerkvist AC, Furebring C \& Borrebaeck CA 1995 Single, antigen-specific $\mathrm{B}$ cells used to generate Fab fragments using CD40-mediated amplification or direct PCR cloning. Biotechniques 18 862-869.

Lander ES, Linton LM, Birren B, Nusbaum C, Zody MC, Baldwin J, Devon K, Dewar K, Doyle M, FitzHugh W et al.
2001 Initial sequencing and analysis of the human genome. Nature 409 860-921.

Lash AE, Tolstoshev CM, Wagner L, Schuler GD, Strausberg RL, Riggins GJ \& Altschul SF 2000 SAGEmap: a public gene expression resource. Genome Research 10 1051-1060.

Lavery KS \& King TH 2003 Antisense and RNAi: powerful tools in drug target discovery and validation. Current Opinion in Drug Discovery and Development 6 561-569.

Lewis GD, Figari I, Fendly B, Wong WL, Carter P, Gorman C \& Shepard HM 1993 Differential responses of human tumor cell lines to anti-p185HER2 monoclonal antibodies. Cancer Immunology Immunotherapy 37 255-263.

Lisitsyn N \& Wigler M 1993 Cloning the differences between two complex genomes. Science 259 946-951.

Liu B, Conrad F, Cooperberg MR, Kirpotin DB \& Marks JD 2004 Mapping tumor epitope space by direct selection of single-chain Fv antibody libraries on prostate cancer cells. Cancer Research 64 704-710.

Liu C, Tadayoni BM, Bourret LA, Mattocks KM, Derr SM, Widdison WC, Kedersha NL, Ariniello PD, Goldmacher VS, Lambert JM et al. 1996 Eradication of large colon tumor xenografts by targeted delivery of maytansinoids. PNAS $\mathbf{9 3}$ 8618-8623.

Liyanage M, Coleman A, du Manoir S, Veldman T, McCormack S, Dickson RB, Barlow C, Wynshaw-Boris A, Janz S, Wienberg J et al. 1996 Multicolour spectral karyotyping of mouse chromosomes. Nature Genetics 14 312-315.

Lockhart DJ, Dong H, Byrne MC, Follettie MT, Gallo MV, Chee MS, Mittmann M, Wang C, Kobayashi M, Horton H et al. 1996 Expression monitoring by hybridization to high-density oligonucleotide arrays. Nature Biotechnology 14 1675-1680.

Ludwig DL, Pereira DS, Zhu Z, Hicklin DJ \& Bohlen P 2003 Monoclonal antibody therapeutics and apoptosis. Oncogene 22 9097-9106.

Luwor RB, Johns TG, Murone C, Huang HJ, Cavenee WK, Ritter G, Old LJ, Burgess AW \& Scott AM 2001 Monoclonal antibody 806 inhibits the growth of tumor xenografts expressing either the de2-7 or amplified epidermal growth factor receptor (EGFR) but not wild-type EGFR. Cancer Research 61 5355-5361.

Lynch TJ, Bell DW, Sordella R, Gurubhagavatula S, Okimoto RA, Brannigan BW, Harris PL, Haserlat SM, Supko JG, Haluska FG et al. 2004 Activating mutations in the epidermal growth factor receptor underlying responsiveness of nonsmall-cell lung cancer to gefitinib. New England Journal of Medicine 350 2129-2139.

Maloney DG, Smith B \& Rose A 2002 Rituximab: mechanism of action and resistance. Seminars in Oncology 29 2-9.

Mao W, Luis E, Ross S, Silva J, Tan C, Crowley C, Chui C, Franz G, Senter P, Koeppen H et al. 2004 EphB2 as a therapeutic antibody drug target for the treatment of colorectal cancer. Cancer Research 64 781-788.

Martin DB, Gifford DR, Wright ME, Keller A, Yi E, Goodlett DR, Aebersold R \& Nelson PS 2004 Quantitative proteomic analysis of proteins released by neoplastic prostate epithelium. Cancer Research 64 347-355. 
Melhem R, Hailat N, Kuick R \& Hanash SM 1997 Quantitative analysis of Op18 phosphorylation in childhood acute leukemia. Leukemia 11 1690-1695.

Mendelsohn J 2000 Blockade of receptors for growth factors: an anticancer therapy - the fourth annual Joseph H Burchenal American Association of Cancer Research Clinical Research Award Lecture. Clinical Cancer Research 6 747-753.

Mendez MJ, Green LL, Corvalan JRF, Jia XC, Maynard-Currie CE, Yang X-D, Gallo ML, Louie DM, Lee DV, Erickson KL et al. 1997 Functional transplant of megabase human immunoglobulin loci recapitulates human antibody response in mice. Nature Genetics 15 146-156.

Mendoza N, Phillips GL, Silva J, Schwall R \& Wickramasinghe D 2002 Inhibition of ligand-mediated HER2 activation in androgen-independent prostate cancer. Cancer Research 62 $5485-5488$.

Milenic DE 2002 Monoclonal antibody-based therapy strategies: providing options for the cancer patient. Current Pharmacological Description 8 1749-1764.

Mintz PJ, Kim J, Do KA, Wang X, Zinner RG, Cristofanilli M, Arap MA, Hong WK, Troncoso P, Logothetis CJ et al. 2003 Fingerprinting the circulating repertoire of antibodies from cancer patients. Nature Biotechnology 21 57-63.

Miraglia S, Swartzman EE, Mellentin-Michelotti J, Evangelista L, Smith C, Gunawan II, Lohman K, Goldberg EM, Manian B \& Yuan PM 1999 Homogeneous cell- and bead-based assays for high throughput screening using fluorometric microvolume assay technology. Journal of Biomolecular Screening 4 193-204.

Mishima K, Johns TG, Luwor RB, Scott AM, Stockert E, Jungbluth AA, Ji XD, Suvarna P, Voland JR, Old LJ et al. 2001 Growth suppression of intracranial xenografted glioblastomas overexpressing mutant epidermal growth factor receptors by systemic administration of monoclonal antibody (mAb) 806, a novel monoclonal antibody directed to the receptor. Cancer Research 61 5349-5354.

Mitchell P 2002 A perspective on protein microarrays. Nature Biotechnology 20 225-229.

Mogensen J, Kolvraa S, Hindkjaer J, Petersen S, Koch J, Nygard M, Jensen T, Gregersen N, Junker S \& Bolund L 1991 Nonradioactive, sequence-specific detection of RNA in situ by primed in situ labeling (PRINS). Experimental Cell Research 196 92-98.

Moscatello DK, Holgado-Madruga M, Godwin AK, Ramirez G, Gunn G, Zoltick PW, Biegel JA, Hayes RL \& Wong AJ 1995 Frequent expression of a mutant epidermal growth factor receptor in multiple human tumors. Cancer Research $\mathbf{5 5}$ 5536-5539.

Nasdala I, Wolburg-Buchholz K, Wolburg H, Kuhn A, Ebnet K, Brachtendorf G, Samulowitz U, Kuster B, Engelhardt B, Vestweber D et al. 2002 A transmembrane tight junction protein selectively expressed on endothelial cells and platelets. Journal of Biological Chemistry 277 16294-16303.

Nederlof PM, van der Flier S, Wiegant J, Raap AK, Tanke HJ, Ploem JS \& van der Ploeg M 1990 Multiple fluorescence in situ hybridization. Cytometry 11 126-131.

Nielsen UB, Kirpotin DB, Pickering EM, Hong K, Park JW, Refaat Shalaby M, Shao Y, Benz CC \& Marks JD 2002 Therapeutic efficacy of anti-ErbB2 immunoliposomes targeted by a phage antibody selected for cellular endocytosis. Biochimica et Biophysica Acta 1591 109-118.

Nilsson F, Kosmehl H, Zardi L \& Neri D 2001 Targeted delivery of tissue factor to the ED-B domain of fibronectin, a marker of angiogenesis, mediates the infarction of solid tumors in mice. Cancer Research 61 711-716.

O'Farrell PH 1975 High resolution two-dimensional electrophoresis of proteins. Journal of Biological Chemistry 250 4007-4021.

Oh JM, Brichory F, Puravs E, Kuick R, Wood C, Rouillard JM, Tra J, Kardia S, Beer D \& Hanash S 2001 A database of protein expression in lung cancer. Proteomics 1 1303-1319.

Old LJ \& Chen YT 1998 New paths in human cancer serology. Journal of Experimental Medicine 187 1163-1167.

Olsson L \& Kaplan HS 1980 Human-human hybridomas producing monoclonal antibodies of predefined antigenic specificity. PNAS 77 5429-5431.

Ostergaard M, Rasmussen HH, Nielsen HV, Vorum H, Orntoft TF, Wolf H \& Celis JE 1997 Proteome profiling of bladder squamous cell carcinomas: identification of markers that define their degree of differentiation. Cancer Research $\mathbf{5 7}$ 4111-4117.

Paez JG, Janne PA, Lee JC, Tracy S, Greulich H, Gabriel S, Herman P, Kaye FJ, Lindeman N, Boggon TJ et al. 2004 EGFR mutations in lung cancer: correlation with clinical response to gefitinib therapy. Science 304 1497-1500.

Pancook JD, Beuerlein G, Pecht G, Tang Y, Nie Y, Wu H, Huse WD \& Watkins JD 2001 In vitro affinity maturation of human IgM antibodies reactive with tumor-associated antigens. Hybrid Hybridomics 20 383-396.

Pasqualini R \& Arap W 2004 Hybridoma-free generation of monoclonal antibodies. PNAS 101 257-259.

Patterson SD \& Aebersold RH 2003 Proteomics: the first decade and beyond. Nature Genetics 33 (Suppl) 311-323.

Payne G 2003 Progress in immunoconjugate cancer therapeutics. Cancer Cell 3 207-212.

Perou CM, Sorlie T, Eisen MB, van de Rijn M, Jeffrey SS, Rees CA, Pollack JR, Ross DT, Johnsen H, Akslen LA et al. 2000 Molecular portraits of human breast tumours. Nature 406 $747-752$.

Pinkel D, Segraves R, Sudar D, Clark S, Poole I, Kowbel D, Collins C, Kuo WL, Chen C, Zhai Y et al. 1998 High resolution analysis of DNA copy number variation using comparative genomic hybridization to microarrays. Nature Genetics 20 207-211.

Poul MA, Becerril B, Nielsen UB, Morisson P \& Marks JD 2000 Selection of tumor-specific internalizing human antibodies from phage libraries. Journal of Molecular Biology 301 1149-1161.

Presta LG 2002 Engineering antibodies for therapy. Current Pharmaceutical Biotechnology 3 237-256.

Rangel LB, Sherman-Baust CA, Wernyj RP, Schwartz DR, Cho KR \& Morin PJ 2003 Characterization of novel human ovarian cancer-specific transcripts (HOSTs) identified by serial analysis of gene expression. Oncogene 22 7225-7232.

Reiter RE, Gu Z, Watabe T, Thomas G, Szigeti K, Davis E, Wahl M, Nisitani S, Yamashiro J, Le Beau MM et al. 1998 Prostate stem cell antigen: a cell surface marker overexpressed in prostate cancer. PNAS 95 1735-1740. 
Ridgway JB, Ng E, Kern JA, Lee J, Brush J, Goddard A \& Carter P 1999 Identification of a human anti-CD55 singlechain Fv by subtractive panning of a phage library using tumor and nontumor cell lines. Cancer Research 59 2718-2723.

Ross J, Gray K, Schenkein D, Greene B, Gray GS, Shulok J, Worland PJ, Celniker A \& Rolfe M $2003 a$ Antibody-based therapeutics in oncology. Expert Review of Anticancer Therapy 3 107-121.

Ross JS, Fletcher JA, Linette GP, Stec J, Clark E, Ayers M, Symmans WF, Pusztai L \& Bloom KJ 2003b The Her-2/neu gene and protein in breast cancer 2003: biomarker and target of therapy. Oncologist 8 307-325.

Ross S, Spencer SD, Holcomb I, Tan C, Hongo J, Devaux B, Rangell L, Keller GA, Schow P, Steeves RM et al. 2002 Prostate stem cell antigen as therapy target: tissue expression and in vivo efficacy of an immunoconjugate. Cancer Research 62 2546-2553.

Ruan Y, Le Ber P, Hui Ng H \& Liu ET 2004 Interrogating the transcriptome. Trends in Biotechnology 22 23-30.

Rubin MA, Dunn R, Strawderman M \& Pienta KJ 2002 Tissue microarray sampling strategy for prostate cancer biomarker analysis. American Journal of Surgical Pathology 26 312-319.

Russo G, Zegar C \& Giordano A 2003 Advantages and limitations of microarray technology in human cancer. Oncogene 22 6497-6507.

Saha S, Sparks AB, Rago C, Akmaev V, Wang CJ, Vogelstein B, Kinzler KW \& Velculescu VE 2002 Using the transcriptome to annotate the genome. Nature Biotechnology 20 508-512.

Sahin U, Tureci O, Schmitt H, Cochlovius B, Johannes T, Schmits R, Stenner F, Luo G, Schobert I \& Pfreundschuh M 1995 Human neoplasms elicit multiple specific immune responses in the autologous host. PNAS 92 11810-11813.

Salgaller ML 2003 Technology evaluation: bevacizumab, Genentech/Roche. Current Opinion in Molecular Therapeutics 5 657-667.

Sauter G, Simon R \& Hillan K 2003 Tissue microarrays in drug discovery. Nature Reviews Drug Discovery 2 962-972.

Schena M, Shalon D, Davis RW \& Brown PO 1995 Quantitative monitoring of gene expression patterns with a complementary DNA microarray. Science 270 467-470.

Schlom J 1991 Antibodies in cancer therapy: basic principles of monoclonal antibodies. In Biologic Therapy of Cancer, pp 464-481. Eds VT De Vita Jr, S Hellman, SA Rosenberg. Philadelphia, PA: JB Lippincott.

Schulz H, Winkler U, Staak JO \& Engert A 2000 The monoclonal antibodies Campath-1h and Rituximab in the therapy of chronic lymphocytic leukemia. Onkologie 23 526-532.

Sehgal A 2003 Anticancer drug discovery using chemical genomics. Current Medicinal Chemistry 10 749-755.

Shi SR, Cote RJ \& Taylor CR 1997 Antigen retrieval immunohistochemistry: past, present, and future. Journal of Histochemistry and Cytochemistry 45 327-343.

Shi SR, Cote RJ \& Taylor CR 2001 Antigen retrieval techniques: current perspectives. Journal of Histochemistry and Cytochemistry 49 931-937.

Simon R, Nocito A, Hubscher T, Bucher C, Torhorst J, Schraml $\mathrm{P}$, Bubendorf L, Mihatsch MM, Moch H, Wilber K et al. 2001 Patterns of her-2/neu amplification and overexpression in primary and metastatic breast cancer. Journal of the National Cancer Institute 93 1141-1146.

Slamon D \& Pegram M 2001 Rationale for trastuzumab (Herceptin) in adjuvant breast cancer trials. Seminars in Oncology 28 13-19.

Slamon DJ, Clark GM, Wong SG, Levin WJ, Ullrich A \& McGuire WL 1987 Human breast cancer: correlation of relapse and survival with amplification of the HER-2/neu oncogene. Science 235 177-182.

Slamon DJ, Godolphin W, Jones LA, Holt JA, Wong SG, Keith DE, Levin WJ, Stuart SG, Udove J, Ullrich A et al. 1989 Studies of the HER-2/neu proto-oncogene in human breast and ovarian cancer. Science 244 707-712.

Slamon DJ, Leyland-Jones B, Shak S, Fuchs H, Paton V, Bajamonde A, Fleming T, Eiermann W, Wolter J, Pegram M et al. 2001 Use of chemotherapy plus a monoclonal antibody against HER2 for metastatic breast cancer that overexpresses HER2. New England Journal of Medicine 344 783-792.

Slaughter DP, Southwick HW \& Smejkal W 1953 Field cancerization in oral stratified squamous epithelium; clinical implications of multicentric origin. Cancer 6 963-968.

Sliwkowski MX, Lofgren JA, Lewis GD, Hotaling TE, Fendly BM \& Fox JA 1999 Nonclinical studies addressing the mechanism of action of trastuzumab (Herceptin). Seminars in Oncology 26 60-70.

Smith DL, Evans CA, Pierce A, Gaskell SJ \& Whetton AD 2002 Changes in the proteome associated with the action of $\mathrm{Bcr}-\mathrm{Abl}$ tyrosine kinase are not related to transcriptional regulation. Molecular and Cellular Proteomics 1 876-884.

Solinas-Toldo S, Lampel S, Stilgenbauer S, Nickolenko J, Benner A, Dohner H, Cremer T \& Lichter P 1997 Matrix-based comparative genomic hybridization: biochips to screen for genomic imbalances. Genes Chromosomes Cancer 20 399-407.

Sonnhammer EL, Eddy SR, Birney E, Bateman A \& Durbin R 1998 Pfam: multiple sequence alignments and HMM-profiles of protein domains. Nucleic Acids Research 26 320-322.

Sørlie T, Perou CM, Tibshirani R, Aas T, Geisler S, Johnsen H, Hastie T, Eisen MB, van de Rijn M, Jeffrey SS et al. 2001 Gene expression patterns of breast carcinomas distinguish tumor subclasses with clinical implications. PNAS 98 10869-10874.

Souchelnytskyi S 2002 Proteomics in studies of signal transduction in epithelial cells. Journal of Mammary Gland Biology and Neoplasia 7 359-371.

Speicher MR, Gwyn Ballard S \& Ward DC 1996 Karyotyping human chromosomes by combinatorial multi-fluor FISH. Nature Genetics 12 368-375.

Steinitz M, Klein G, Koskimies S \& Makel O 1977 EB virusinduced B lymphocyte cell lines producing specific antibody. Nature 269 420-422.

Strausberg RL, Simpson AJ \& Wooster R 2003 Sequence-based cancer genomics: progress, lessons and opportunities. Nature Reviews Genetics 4 409-418.

Sturla LM, Merrick AE \& Burchill SA 2003 FGFR3IIIS: a novel soluble FGFR3 spliced variant that modulates growth is frequently expressed in tumour cells. British Journal of Cancer 89 1276-1284.

Sugawa N, Ekstrand AJ, James CD \& Collins VP 1990 Identical splicing of aberrant epidermal growth factor receptor 
transcripts from amplified rearranged genes in human glioblastomas. PNAS 87 8602-8606.

Tabor MP, Brakenhoff RH, van Houten VM, Kummer JA, Snel MH, Snijders PJ, Snow GB, Leemans CR \& Braakhuis BJ 2001 Persistence of genetically altered fields in head and neck cancer patients: biological and clinical implications. Clinical Cancer Research 7 1523-1532.

Tabor MP, Brakenhoff RH, Ruijter-Schippers HJ, Kummer JA, Leemans CR \& Braakhuis BJ 2004 Genetically altered fields as origin of locally recurrent head and neck cancer: a retrospective study. Clinical Cancer Research 10 3607-3613.

Tanimoto M, Scheinberg DA, Cordon-Cardo C, Huie D, Clarkson BD \& Old LJ 1989 Restricted expression of an early myeloid and monocytic cell surface antigen defined by monoclonal antibody M195. Leukemia 3 339-348.

Tanner M, Gancberg D, Di Leo A, Larsimont D, Rouas G, Piccart MJ \& Isola J 2000 Chromogenic in situ hybridization : a practical alternative for fluorescence in situ hybridization to detect HER-2/neu oncogene amplification in archival breast cancer samples. American Journal of Pathology 157 1467-1472.

Tao WA \& Aebersold R 2003 Advances in quantitative proteomics via stable isotope tagging and mass spectrometry. Current Opinion in Biotechnology 14 110-118.

Tomizuka K, Shinohara T, Yoshida H, Uejima H, Ohguma A, Tanaka S, Sato K, Oshimura M \& Ishida I 2000 Double trans-chromosomic mice: maintenance of two individual human chromosome fragments containing Ig heavy and $\kappa$ loci and expression of fully human antibodies. PNAS 97 722-727.

Tornell J \& Snaith M 2002 Transgenic systems in drug discovery: from target identification to humanized mice. Drug Discovery Today 7 461-470.

Tubbs R, Pettay J, Skacel M, Powell R, Stoler M, Roche P \& Hainfeld J 2002 Gold-facilitated in situ hybridization: a bright-field autometallographic alternative to fluorescence in situ hybridization for detection of Her-2/neu gene amplification. American Journal of Pathology 160 1589-1595.

al-Tubuly AA, Luqmani YA, Shousha S, Melcher D \& Ritter MA 1996 Differential expression of gp200-MR6 molecule in benign hyperplasia and down-regulation in invasive carcinoma of the breast. British Journal of Cancer $\mathbf{7 4}$ 1005-1011.

Vaughan TJ, Williams AJ, Pritchard K, Osbourn JK, Pope AR, Earnshaw JC, McCafferty J, Hodits RA, Wilton J \& Johnson KS 1996 Human antibodies with sub-nanomolar affinities isolated from a large non-immunized phage display library. Nature Biotechnology 14 309-314.

van't Veer LJ, Dai H, van de Vijver MJ, He YD, Hart AA, Mao M, Peterse HL, van der Kooy K, Marton MJ, Witteveen AT et al. 2002 Gene expression profiling predicts clinical outcome of breast cancer. Nature $\mathbf{4 1 5} 530-536$.

Velculescu VE, Zhang L, Vogelstein B \& Kinzler KW 1995 Serial analysis of gene expression. Science 270 484-487.

van der Velden VH, Hochhaus A, Cazzaniga G, Szczepanski T, Gabert J \& van Dongen JJ 2003 Detection of minimal residual disease in hematologic malignancies by real-time quantitative PCR: principles, approaches, and laboratory aspects. Leukemia 17 1013-1034.
Venter JC, Adams MD, Myers EW, Li PW, Mural RJ, Sutton GG, Smith HO, Yandell M, Evans CA, Holt RA et al. 2001 The sequence of the human genome. Science 291 1304-1351.

Vogel CL, Cobleigh MA, Tripathy D, Gutheil JC, Harris LN, Fehrenbacher L, Slamon DJ, Murphy M, Novotny WF, Burchmore M et al. 2002 Efficacy and safety of trastuzumab as a single agent in first-line treatment of HER2overexpressing metastatic breast cancer. Journal of Clinical Oncology 20 719-726.

Vollmers HP \& Brändlein S 2002 Nature's best weapons to fight cancer. Revival of human monoclonal IgM antibodies. Human Antibodies 11 131-142.

Vollmers HP, O’Connor R, Muller J, Kirchner T \& MullerHermelink HK 1989 SC-1, a functional human monoclonal antibody against autologous stomach carcinoma cells. Cancer Research 49 2471-2476.

Wedemeyer N \& Potter T 2001 Flow cytometry: an 'old' tool for novel applications in medical genetics. Clinical Genetics $\mathbf{6 0}$ $1-8$.

Wielenga VJ, Heider KH, Offerhaus GJ, Adolf GR, van den Berg FM, Ponta H, Herrlich P \& Pals ST 1993 Expression of CD44 variant proteins in human colorectal cancer is related to tumor progression. Cancer Research 53 4754-4756.

Wikstrand CJ, Hale LP, Batra SK, Hill ML, Humphrey PA, Kurpad SN, McLendon RE, Moscatello D, Pegram CN, Reist CJ et al. 1995 Monoclonal antibodies against EGFRvIII are tumor specific and react with breast and lung carcinomas and malignant gliomas. Cancer Research 55 3140-3148.

Williams AF, Galfre G \& Milstein C 1977 Analysis of cell surfaces by xenogeneic myeloma-hybrid antibodies: differentiation antigens of rat lymphocytes. Cell 12 663-673.

Wittwer CT, Herrmann MG, Gundry CN \& Elenitoba-Johnson KS 2001 Real-time multiplex PCR assays. Methods 25 430-442.

Wu CC \& Yates JR 3rd 2003 The application of mass spectrometry to membrane proteomics. Nature Biotechnology 21 262-267.

Wu CC, MacCoss MJ, Howell KE \& Yates JR 3rd 2003 A method for the comprehensive proteomic analysis of membrane proteins. Nature Biotechnology 21 532-538.

Wulfkuhle JD, Sgroi DC, Krutzsch H, McLean K, McGarvey K, Knowlton M, Chen S, Shu H, Sahin A, Kurek R et al. 2002 Proteomics of human breast ductal carcinoma in situ. Cancer Research 62 6740-6749.

Xi X, Roane DS, Zhou J, Ryan DH \& Martin RJ 2003 Doublecolor fluorescence in situ hybridization with RNA probes. Biotechniques 34 914-916, 918.

Yang XD, Jia XC, Corvalan JRF, Wang P, Davis CG \& Jakobovits A 1999 Eradication of established tumors by a fully human monoclonal antibody to the epidermal growth factor receptor without concomitant chemotherapy. Cancer Research 59 1236-1243.

Yaziji H \& Gown AM 2002 Testing for HER-2/neu in breast cancer: is fluorescence in situ hybridization superior in predicting outcome? Advances in Anatomical Pathology 9 338-344.

Zardi L, Carnemolla B, Siri A, Petersen TE, Paolella G, Sebastio G \& Baralle FE 1987 Transformed human cells produce a 
new fibronectin isoform by preferential alternative splicing of a previously unobserved exon. EMBO Journal 6 2337-2342.

Zhang L, Zhou W, Velculescu VE, Kern SE, Hruban RH, Hamilton SR, Vogelstein B \& Kinzler KW 1997 Gene expression profiles in normal and cancer cells. Science $\mathbf{2 7 6}$ $1268-1272$.

Zhao J, Wu R, Au A, Marquez A, Yu Y \& Shi Z 2002 Determination of HER2 gene amplification by chromogenic in situ hybridization (CISH) in archival breast carcinoma. Modern Pathology 15 657-665.

Zhou G, Li H, DeCamp D, Chen S, Shu H, Gong Y, Flaig M, Gillespie JW, Hu N, Taylor PR et al. 2002a 2D differential ingel electrophoresis for the identification of esophageal scans cell cancer-specific protein markers. Molecular and Cellular Proteomics 1 117-124.
Zhou H, Ranish JA, Watts JD \& Aebersold R $2002 b$ Quantitative proteome analysis by solid-phase isotope tagging and mass spectrometry. Nature Biotechnology 20 512-515.

Zhumabayeva B, Diatchenko L, Chenchik A \& Siebert PD 2001 Use of SMART-generated cDNA for gene expression studies in multiple human tumors. Biotechniques 30 158-163.

Ziai MR, Imberti L, Nicotra MR, Badaracco G, Segatto O, Natali PG \& Ferrone S 1987 Analysis with monoclonal antibodies of the molecular and cellular heterogeneity of human high molecular weight melanoma associated antigen. Cancer Research 47 2474-2480.

Zijlstra A, Testa JE \& Quigley JP 2003 Targeting the proteome/ epitome, implementation of subtractive immunization. Biochemical and Biophysical Research Communications $\mathbf{3 0 3}$ 733-744. 